\title{
KIELIKÄSITYKSET VANHUSTYÖSSÄ - ASUKKAIDEN, HOITAJIEN JA ESIMIESTEN KÄSITYKSIÄ HYVÄSTÄ VUOROVAIKUTUKSESTA JA KIELENKÄYTÖSTÄ
}

\author{
Anne Mäntynen, Suomalais-ugrilainen osasto, \\ Helsingin yliopisto \\ Sanna Tapionkaski, Kieli- ja viestintätieteiden laitos, \\ Jyväskylän yliopisto \\ Sari Pietikäinen, Kieli- ja viestintätieteiden laitos, \\ Jyväskylän yliopisto
}

\begin{abstract}
Artikkelissa tarkastellaan käsityksiä hyvästä vuorovaikutuksesta ja kielenkäytöstä vanhainkodissa kriittistä diskurssintutkimusta ja etnografiaa hyödyntäen. Tutkimus perustuu aineistoon, joka kerättiin haastattelemalla ja havainnoimalla asukkaita, hoitajia ja esimiehiä kahdessa monikielisessä vanhusten hoitoyksikössä. Aineistosta analysoitiin vanhustyön kieleen liittyviä kieli-ideologioita ja metakieltä. Analyysin tuloksena nousi esiin neljä keskeistä vanhuslähtöisen kielen ulottuvuutta: (1) vuorovaikutuksen laatu, määrä ja sävy, (2) puhuttelun ja nimeämisen tavat, (3) äidinkieli ja monikielisyys sekä (4) kosketuksen ja muun multimodaalisen vuorovaikutuksen merkitys. Tulokset tuovat esiin, että vanhainkoti on institutionaalinen paikka, joka on asukkaille koti ja hoitajille ja esimiehille työpaikka. Nämä toisistaan poikkeavat positiot luovat erilaisia tarpeita ja toiveita vuorovaikutukselle ja kielenkäytölle: siinä missä hoitajat pyrkivät tekemään työnsä tarkoituksenmukaisesti ja sujuvoittamaan hoitoarkea, asukkaat kaipasivat keskustelua, rupattelua ja yhteistä toimintaa hoivakodin arkeen. Hoitajien kielikäsityksissä korostuvat puheen ymmärrettävyys ja selkeys, asukkailla kielen sosiaalinen merkitys, keskustelu ja kuunteleminen. Tulokset kertovat myös siitä, että vanhusten keskinäinen tuettu vuorovaikutus ja musiikin aktivoiva käyttö voisivat olla keinoja lisätä vanhuksia osallistavaa vuorovaikutusta vanhainkodissa.
\end{abstract}

Avainsanat: diskurssintutkimus, etnografia, kieli-ideologiat, kielikäsitykset, osallistava vuorovaikutus, vanhuslähtöinen kieli

Kirjoittajien yhteystiedot:

Anne Mäntynen

anne.mantynen@helsinki.fi

Sanna Tapionkaski

sanna.j.tapionkaski@jyu.fi

Sari Pietikäinen

sari.p.pietikainen@jyu.fi

\section{JOHDANTO}

Vanhustyön kehittäminen on Suomessa ollut pitkään lääketiede- ja psykiatriakeskeistä. Sen sijaan vanhusten kielenkäyttöä ja vuorovaikutusta on tutkittu jokseenkin vähän ja usein fokus on ollut kielellisen kyvyn heikkenemisessä (ks. lukua 2.1). Vasta aivan 
viimeaikaisessa kielentutkimuksessa on ongelmakeskeisyyden sijaan korostettu ratkaisukeskeisyyttä: vanhusten kommunikointi voi olla käytännöllistä selviytymistä mahdollisimman tarkoituksenmukaisilla tavoilla monikielisissäkin tilanteissa (ks. esim. Mononen, 2016; Plejert, Lindholm \& Schrauf, 2017). On siis perusteltua tarkastella myös sitä, mitä kielestä ja kielenkäytöstä ajatellaan vanhustyön kentällä.

Tämä artikkeli perustuu monitieteiseen tutkimushankkeeseen, jonka tavoitteena on tutkia ja kehittää vanhuslähtöistä kieltä ja sellaisia vuorovaikutusmalleja, jotka vahvistavat vanhusten osallisuutta hoitoarjessa sekä lisäävät kuuntelevaa ja osallistavaa vuorovaikutusta. Artikkelin tavoitteena on selvittää, millaista on vanhuslähtöinen kieli asukkaiden ${ }^{1}$, hoitajien ja esimiesten näkökulmasta. Tarkastelun kohteena ovat käsitykset hyvästä ja toimivasta kielestä vanhustyössä. Näin tutkimuksemme kytkeytyy erityisesti kieliideologioiden ja metakielen tutkimukseen diskurssintutkimuksen viitekehyksessä (ks. tarkemmin lukua 2.2). Erityisesti kysymme, mitä kielen ja vuorovaikutuksen piirteitä ja osa-alueita asukkaat, hoitajat ja esimiehet ottavat ylipäätään esiin, mitä he pitävät tärkeinä vanhustyössä ja millaisia eroja ja yhtäläisyyksiä heidän käsityksissään on. ${ }^{2}$

Tutkimushankkeemme pilotointivaiheen aineistonkeruu toteutettiin syksyllä 2016 osana erään kunnan kehittämishanketta, jossa tavoitteena oli kehittää vanhustyötä kunnan vanhuspalveluissa kokonaisuutena. Hankkeessamme on tarkasteltu arjen kieli- ja vuorovaikutuskäytänteitä sekä näihin liittyviä kokemuksia ja käsityksiä muistisairaiden

1 Käytämme artikkelissa enimmäkseen yleisnimitystä vanhus, mutta oman tutkimusaineistomme yhteydessä puhumme hoitoyksikön ja tehostetun palveluasumisen asukkaista.

2 Esitämme kiitokset artikkelimme nimettömille arvioijille lukuisista hyödyllisistä kommenteista. vanhusten hoitoyksikössä ja tehostetun palveluasumisen toiminnassa. Keskeisenä teoreettisena lähtökohtana on kriittisen diskurssintutkimuksen perusajatus siitä, että kieli on sosiaalista toimintaa ja että kielikäytänteiden muokkaaminen vaikuttaa myös toimintaan ja sosiaalisiin ja yhteiskunnallisiin rakenteisiin (esim. Heller, Pietikäinen \& Pujolar, 2018; Pietikäinen 2016; Pietikäinen \& Mäntynen, 2009).

Kriittisen diskurssintutkimuksen tiedonintressien mukaisesti tutkimuksemme tavoitteena on myös ollut, että tutkimustulokset olisivat mahdollisimman helposti avainhenkilöiden hyödynnettävissä. Katsoimme tavanomaisen kirjoitetun tutkimusraportin jättävän helposti etenkin muistisairauksia sairastavat vanhukset ja heidän omaisensa sekä kiireisen hoitohenkilökunnan ulkopuolisiksi. Tämän vuoksi tulosten jalkauttamistapaa suunniteltiin ja testattiin yhteistyössä etnografisen palvelumuotoilun asiantuntijoiden (ks. Cantarella, Hegel \& Marcus, 2015) ja visualisoijan kanssa. Lopputuloksena on keskeisten tutkimustulosten visualisointi sarjakuvamaiseen muotoon eräänlaiseksi käypä kielisuositus -kuvasarjaksi. Osa tuloksia yleistajuisesti esittelevistä kuvista on mukana tässä artikkelissa havainnollistamassa tulosten jalkauttamista (ks. kuva 1 sekä kuva 2 luvussa 5) 3 .

Kuvasarjan tavoitteena on mahdollistaa jokaiselle tutkimukseen osallistuneelle pääsy tutkimustuloksiin ja tarjota peilauspintaa kunkin omille käytänteille ja toiveille. $\mathrm{Ku}$ vasarjan pohjana on hyödynnetty omien havaintojemme lisäksi aiemman tutkimuksen tuloksia, ja siinä on pyritty erityisesti nostamaan esiin hyviä käytänteitä. Kuvat eivät toisin sanoen esitä tutkimustuloksia sellaisinaan vaan ovat niiden pohjalta tehtyjä kiteytyksiä

3 Kuvat on toteuttanut Redanredan Oy, joka oli hankkeen loppuvaiheessa mukana visualisoimassa tutkimustuloksia. 
Kuva 1. Hyvä vuorovaikutus ja kielenkäyttö vanhustyössä.
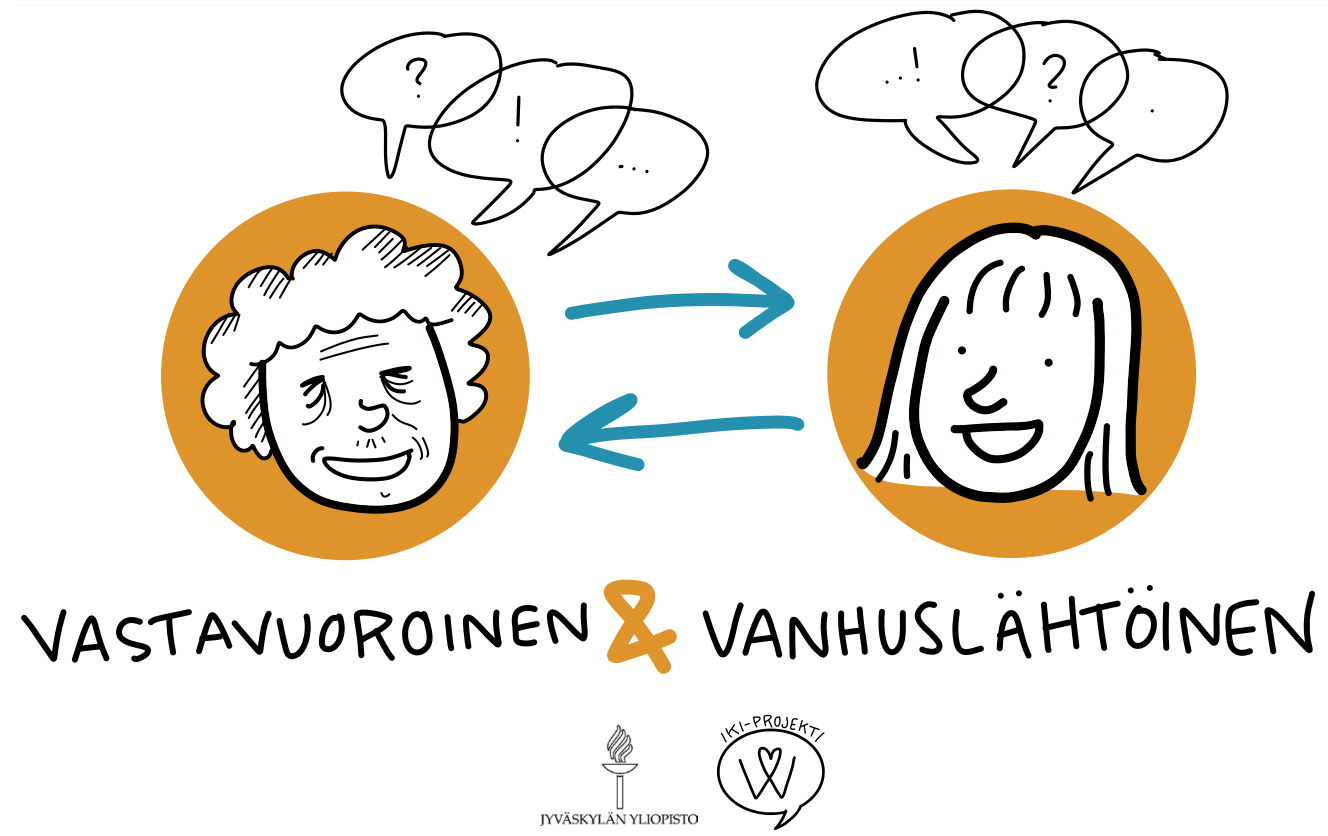

siitä, mitä tutkittavat itse sekä aiempi tutkimus pitävät hyvinä kielikäytänteinä vanhustyössä.

Käymme seuraavaksi luvussa 2 tiiviisti läpi aiempaa vanhuuden kielen tutkimusta ja esittelemme metakielen ja kieli-ideologioiden tutkimuksen kannalta keskeisimmät käsitteemme. Sen jälkeen siirrymme tutkimusasetelman ja tulosten esittelyyn luvuissa 3 ja 4. Luvussa 5 pohdimme tulosten merkitystä laajemmin ja kytkemme ne laajempaan yhteiskunnalliseen ja sosiaaliseen toimintaympäristöön.

\section{TEOREETTINEN TAUSTA}

\subsection{Aiempi vanhuuden kielen tutkimus}

Vanhuuteen liittyvää kieltä ja kielenkäyttöä on tutkittu jonkin verran, mutta esimerkiksi Suomessa niin sanottu gerontologinen lingvistiikka on kytkeytynyt geriatrisen hoidon ja vanhustyön kehittämiseen ja ollut lääketiede- ja psykiatriakeskeistä (Kivelä, 2006).
Tutkimuksen fokus on etenkin aiemmin ollut kielellisen kyvyn heikkenemisessä eritoten muistisairaiden ihmisten kohdalla (Markkola, 2003). Huomiota on kuitenkin kiinnitetty myös normaaliin ikääntymiseen liittyviin kielellisiin muutoksiin tai muuttumattomuuksiin: kognitiivisten kykyjen ja kuulon heikkeneminen voivat johtaa ongelmiin vuorovaikutustilanteissa, mutta kokonaisuutena useat kielelliset taidot säilyvät terveillä vanhuksilla pitkään muuttumattomina (kokoavasti aiemmasta tutkimuksesta ks. Pekkala, 2011). Kansainvälisessä kielentutkimuksessa taas on tarkasteltu monikielisyyttä kognitiivisena resurssina (ks. esim. Bialystok, Abutalebi, Bak, Burke \& Kroll, 2016) sekä kiinnitetty laajemmin huomiota erityisesti hoitohenkilökunnan ja vanhusten väliseen vuorovaikutukseen ja hoitohenkilökunnan kielenkäyttöön hoivainstituutioissa (ks. esim. Backhaus, 2009; Carpiac-Claver \& Levy-Storms, 2007; Grainger, 1993, 1998, 2004; Makkinga, 2017; Makoni \& Grainger, 2002; Marsden \& Holmes, 2014). 
Katsauksessaan aiempaan tutkimukseen Marsden ja Holmes (2014, s. 17-18) toteavat, että tutkimus on antanut jokseenkin yksioikoisen kuvan vanhuksiin liittyvästä vuorovaikutuksesta hoivainstituutioissa: vanhusten omaa puhetta ei ole juuri analysoitu eikä vuorovaikutustilanteita ole kontekstualisoitu. Runsaasti huomiota on kiinnitetty niin kutsuttuun vanhuspubeeseen eli vanhuksille mukautettuun, yksinkertaistettuun puheeseen, jolla on havaittu olevan runsaasti yhtymäkohtia lapsille suunnatun puheen kanssa ('elderspeak', ks. Marsden \& Holmes, 2014, s. 18-19), sekä hoivapuheeseen, jota luonnehtii aidon välittämisen sijaan tarve suoriutua hoitotoimenpiteistä mahdollisimman tehokkaasti (Marsden \& Holmes, 2014, s. 19; Makoni \& Grainger, 2002, s. 806-807). Ylipäätään tutkimuksissa on havaittu, että niin henkilökunnan ja asukkaiden välinen kuin asukkaiden keskinäinen vuorovaikutus voi olla hyvin vähäistä (yhteenveto aiemmasta tutkimuksesta ks. Grainger, 2004, s. 480-482). Ongelmallisena pidetyn hoitohenkilökunnan kielenkäytön sijaan Marsdenin ja Holmesin (2014) oma tutkimus on kiinnittänyt enemmän huomiota vuorovaikutustilanteissa ilmenevään neuvotteluun ja solidaarisuuteen, joiden avulla ylläpidetään positiivisia suhteita hoitajien ja vanhusten välillä. Myös muu viimeaikainen tutkimus osoittaa, että sekä laitoksissa pitkäaikaisesti asuvien että kotihoidon piirissä olevien vanhusten kielenkäyttöä voidaan tarkastella ongelmakeskeisyyden sijasta ratkaisukeskeisesti: kommunikointi on esimerkiksi käytännöllistä selviytymistä mahdollisimman tarkoituksenmukaisilla tavoilla monikielisissäkin tilanteissa, ja niin muistisairailla kuin heidän hoitajillaan on monenlaisia selviytymiskeinoja vaikeissa puhetilanteissa (Heinemann, 2009; Jansson, 2014; Jansson \& Plejert, 2014; Korolija, 2000; Korpijaakko-Huuhka, Rantala \& Karjalainen, 2014; Lindholm, 2006, 2012,
2015, 2017; Mononen 2013, 2016; Plejert, Jansson \& Yazdanpanah, 2014; Plejert ym., 2017).

Suomalaisessa tutkimuksessa on tarkasteltu muistisairaiden vanhusten vuorovaikutustilanteita sekä yksi- että monikielisissä hoivaympäristöissä. Monikielisyys voi toimia keskustelussa paitsi resurssina myös erityisenä haasteena (Lindholm, 2017; Mononen, 2016). Vaikka erityisesti kognitiivisesti kuormittavat ryhmäkeskustelut päällekkäispuhuntoineen ja rinnakkaiskeskusteluineen voivat olla muistisairaille haastavia, he voivat pyrkiä aktiivisesti osallistumaan keskusteluun monin tavoin ja auttaa toisiaan seuraamaan keskustelua esimerkiksi korjausaloitteiden tai toistojen avulla (Lindholm, 2012; Mononen, 2016). Kahdenkeskisissä keskusteluissa selviytymisstrategioita voivat olla myös kysymykset, epävarmuuden osoitukset, kiertoilmaukset, eleet ja huumori (KorpijaakkoHuuhka ym., 2014). Muistisairaille vanhuksille on tärkeää ylläpitää tervettä minäkuvaa kertomalla muistoista tai nykyisestä osallistumisesta yhteiskuntaan (Korpijaakko-Huuhka ym., 2014), mutta myös totuudesta poikkeava tarinointi voi toimia keinona osallistua vuorovaikutukseen ja rakentaa positiivista identiteettiä (Lindholm, 2015). Vanhusten erilaisista selviytymisstrategioista huolimatta hoitajan tai puheterapeutin rooli vuorovaikutustilanteiden ohjaajana ja aktivoijana sekä aktiivisena kuuntelijana on keskeinen sekä ryhmä- että yksilötilanteissa (Korpijaakko-Huuhka ym., 2014; Lindholm, 2012, 2015). Kaikkiaan vanhusten kielenkäyttöä ja vuorovaikutusta on kuitenkin tutkittu vielä vähäisesti (ks. Mononen, 2016, s. 30-31), joten erityisesti ratkaisukeskeinen ja vanhusten osallisuutta tarkasteleva lisätutkimus on tarpeen.

Kielellisen kyvyn lisäksi soveltava kielentutkimus on kiinnittänyt huomiota siihen, miten vanhuudesta ja vanhuksista puhutaan: kieli- 
tietoisuuden kehittäminen osana vanhuuden tutkimusta on tullut mukaan soveltavaan kielentutkimukseen 1990-luvulta alkaen (Coupland, 1997; Coupland \& Coupland, 1993). Aiempi tutkimus osoittaa, että vanhuksia ei välttämättä kuulla ja heistä puhutaan usein ikään kuin heidän itsensä ohi. Vanhukset eivät esimerkiksi aina rohkene antaa kriittistä palautetta eivätkä ole mukana palveluiden arviointikäytänteissä tai niistä tietoisia (kotihoidosta ks. Andersson, Haverinen \& Malin, 2004). Sosiaali- ja terveydenhuoltoa ohjaavissa teksteissä puolestaan toimijoina korostuvat ns. aktiiviset vanhustoimijat sekä lääkärit - vähemmälle huomiolle jäävät vanhukset, joiden toimintakyky on rajoittunut. Lisäksi vanhustyötä tekevät käytännön toteuttajat puuttuvat ohjaavista teksteistä lähes kokonaan. Abstrakti virkakieli valuu helposti myös asiakastyöhön, missä se ei palvele käytännön työn kehittämistä yhdessä vanhusten kanssa. (Aaltonen ym., 2009.) Mediateksteissä puolestaan nousee esiin ikäsyrjintä ja vanhuksista puhutaan ongelmallisina tai heikkoina $(\mathrm{mm}$. Cruikshank, 2003; Fealy, McNamara, Treacy \& Lyons, 2012). Tällaiset vanhuuden diskurssit taas vaikuttavat edelleen vanhustyön toimijoiden kielenkäyttöön ja käsityksiin vanhuksista sekä vanhusten omiin käsityksiin itsestään (Coupland \& Coupland, 1993; Makkinga, 2017; Nussbaum, Pitss, Huber, Raup Krieger \& Ohs, 2005); on jopa löydetty yhteys negatiivisten vanhuusstereotypioiden ja Alzheimerin tautiin liittyvien aivojen muutosten välillä (Levy ym., 2016).

Metakielen ja kieli-ideologioiden tutkimuksen kannalta on huomioitava kaksi keskeistä näkökulmaa, kun kehitetään vanhuslähtöistä kieltä ja vuorovaikutusta: 1) vanhukset kielenkäyttäjinä erilaisissa vuorovaikutustilanteissa sekä 2) vanhukset kielellistettyinä tiedon ja toiminnan kohteina. Tässä artikkelissa kiinnitämme huomiota kumpaankin: käsityksiin siitä, miten vanhuk- set puhuvat ja miten heille puhutaan, ja siitä, millä ilmauksilla heihin viitataan ja miten heistä siis puhutaan (nimeäminen).

\subsection{Metakielen ja kieli-ideologioiden tutkimus}

Tarkastelemme tässä artikkelissa vanhuuden kieltä ja kielenkäyttöä erityisesti sitä koskevien käsitysten ja ihanteiden kannalta. Tutkimuksemme liittyy näin sosiolingvistiseen ja diskurssianalyyttiseen tutkimukseen kieliideologioista ja metakielestä. Kieli-ideologioilla tarkoitetaan yleensä kielenkäyttäjien käsityksiä kielestä ja kielenkäytöstä sekä esimerkiksi niiden arvosta, sopivuudesta ja toimivuudesta eri tilanteissa (ks. esim. Kroskrity, 2004; Mäntynen ym., 2012). Kielikäsityksen ja kieli-ideologian käsitteet ovat merkitykseltään läheisiä. Niiden eroa voisi kuvata siten, että kielikäsitykset ovat - tai ainakin voivat olla - jossain määrin yksilöllisiä, kun taas kieli-ideologiat ovat yhteisöllisiä ja yhteydessä muun muassa laajemmin tunnistettaviin, suhteellisen kestäviin kulttuurisiin ja ideologisiin rakenteisiin (ks. esim. Mäntynen ym., 2012; vrt. Saviniemi, 2015, s. 30-33). Kielikäsityksillä viittaamme tässä artikkelissa haastatteluissa esiin nouseviin yksittäisten kielenkäyttäjien näkemyksiin. Kieli-ideologioilla puolestaan tarkoitamme yhteisiä, tunnistettavia käsityksiä kielestä, jollaisiksi tutkimuksemme koottuja tuloksia voi kuvata (ks. lukua 4).

Tarkastelumme kohteena ovat nimenomaan vanhuuteen ja vanhustyöhön liittyvät kieli-ideologiat vanhustyön kontekstissa. Näitä kieli-ideologioita tutkimme analysoimalla vanhustyön toimijoiden käsityksiä ja näkemyksiä kielenkäytöstä erityisesti haastatteluaineiston perusteella. Analyysin pääkohteena on metakieli eli se, mitä kielestä haastatteluissa eksplisiittisesti sanotaan. Metakielen ja metapragmaattisen diskurssin tarkastelu on yksi tapa tutkia kieli-ideologioita (ks. esim. 
Woolard, 1998, s. 9). ${ }^{4}$ Tällöin tutkitaan sitä, mitä kielenkäyttäjät kielestä ja kielikäytänteistä sanovat ja miten he niitä kuvaavat. Metakielen tarkastelu jättää kuitenkin piiloon kielikäytänteissä elävät ideologiat, esimerkiksi sen, miten kieltä todellisuudessa käytetään ja miten kieltä implisiittisesti säädellään (Woolard, 1998, s. 9). Tätä niin sanottua metapragmatiikkaa voi puolestaan tarkastella havainnoimalla ja analysoimalla kielenkäyttöä kontekstissaan esimerkiksi etnografian keinoin sekä haastattelemalla kielenkäyttäjiä, kuten tässä hankkeessa on tehty.

Tutkimuksemme hyödyntää kriittistä diskurssintutkimusta, etnografiaa ja toimintatutkimusta (Heller ym., 2018; Pietikäinen \& Mäntynen, 2009). Kriittinen diskurssintutkimus läpäisee tutkimusotteemme ja näkyy muun muassa dynaamisena kielikäsityksenä sekä ymmärryksenä kielen ja kontekstin välisestä suhteesta: kieltä muuttamalla voi muuttaa käytänteitä ja toimintatapoja. Toisaalta ajan myötä muotoutuneet käytänteet, kirjatut toimintatavat ja säännökset muokkaavat ja rajoittavat sitä, millainen kielenkäyttö ja vuorovaikutus on mahdollista, suotavaa ja tavoiteltavaa. Kriittisen diskurssintutkimuksen ja toimintatutkimuksen periaatteiden mukaisesti tutkimuksemme tavoitteena on tuottaa sellaista tietoa ja sellaisia käytänteitä, jotka auttavat kehittämään vanhustyön kielenkäyttöä ja vuorovaikutusta ja siten vanhusten osallisuutta. Käytännössä tämä tarkoittaa tässä artikkelissa sitä, että analysoimme etnografisesta aineistostamme kieleen ja vuorovaikutukseen liittyvää metakieltä sekä kielikäsityksiä ja kytkemme tulokset laajempaan toimintaympäristöön. Laajempi toimintaympäristö käsittää esimerkiksi sen, mitä ymmärretään

4 Metakielen käsitettä käytetään myös kansanlingvistisessä kielikäsitysten ja kielellisten havaintojen tutkimuksessa (ks. esim. Preston, 2004; Mielikäinen \& Palander, 2014; Saviniemi, 2015, 92-97), jossa tarkastellaan maallikoiden käsityksiä ja puhetta kielestä. hyvänä vanhuutena ja vanhustenhoitona ja millaisia reunaehtoja laajemman kontekstin, esimerkiksi instituution sääntöjen, perinteiden tai taloudellisten resurssien, nähdään asettavan vanhustenhoidolle.

\section{AINEISTO JA MENETELMÄT}

Artikkelin ydinaineisto koostuu hoitotyön arjen kielenkäyttö- ja vuorovaikutustilanteiden havainnoinnista institutionaalisessa kontekstissa sekä asukkaiden ja hoitohenkilökunnan haastatteluista erään kunnan kaksikielisissä vanhuspalveluyksiköissä: muistisairaiden vanhusten hoitoyksikössä ja tehostetussa palveluasumisen toiminnassa. Aineisto kerättiin etnografisesti syksyllä 2016. Se sisältää kolmen tutkijan kahden päivän etnografiset kenttätyöt (havainnointi, ääni- ja kuvanauhoitus sekä valokuvaus yksiköiden yhteisissä tiloissa) sekä viiden asukkaan, viiden työntekijän ja kahden vanhustyötä johtavan henkilön teemahaastattelut. Haastattelut tehtiin pääasiassa kahden kesken, eli niissä olivat läsnä yksi tutkija ja yksi haastateltava. Yhden asukkaan haastattelussa oli mukana myös omainen, ja yhden hoitajan haastattelussa olivat läsnä kaikki kolme tutkijaa. Aineistoa täydentävät kymmenen hoitajan täyttämät kyselylomakkeet sekä kunnalta saatu taustamateriaali, joka sisältää muun muassa esitteitä, tiedotteen sekä yhteenvedon kunnan järjestämistä työpajoista. Pilotissa mukana olevalta kunnalta on saatu tutkimuslupa aineiston keruuseen; haastateltavilta ja tarvittaessa heidän omaisiltaan pyydettiin lisäksi tutkimusluvat erikseen. Aineisto on kaikkiaan saatu tutkimus- ja opetuskäyttöön tutkimusta koskevien eettisten sääntöjen ja tutkimusluvan puitteissa. Tutkittavilta ei ole kerätty yksilöiviä henkilötietoja, ja aineisto on anonymisoitu niin, että tutkittavat eivät ole tunnistettavissa. Toimintatutkimuksen mukaisesti olemme suunnitelleet aineistonkeruuta ja tulosten hyödyntämistä yhdessä hoitoympäristön avainhenkilöiden 
kanssa. Oman leimansa aineistonkeruuseen on tuonut myös se, että kyseessä oli tilaustutkimus, joka oli osin kunnan ja osin Jyväskylän yliopiston rahoittama. Käytännössä tämä on tarkoittanut tilaustutkimuksen ja itsenäisen tieteellisen tutkimustyön tavoitteiden ja käytänteiden yhteensovittamista ja avointa neuvottelua tutkimuksen tavoitteista, aineistonkeruusta ja tulosten hyödyntämisestä.

Tutkimuksemme yhtenä tavoitteena oli selvittää, miten vanhustyön toimijat itse käsittävät vanhuslähtöisen kielen. Tätä selvittelimme ensisijaisesti haastattelemalla asukkaita, hoitajia ja vanhustyön esimiehiä. Haastattelukysymykset oli rakennettu seitsemän teeman ympärille, ja niissä kartoitettiin haastateltavien kokemuksia ja käsityksiä keskusteluilmapiiristä, keskustelukumppaneista, keskustelunaiheista, kielivalinnoista, puhuttelusta, kuuntelemisesta sekä lukemisen ja kirjoittamisen merkityksestä. Haastattelurungossa ei ollut suoraan kysymystä vanhuslähtöisyydestä käsitteenä tai ilmiönä, mutta joissain haastatteluissa se nousi esiin. Haastatteluista osa tehtiin suomeksi ja osa ruotsiksi, ja joissakin ruotsinkielisissä haastatteluissa käytettiin suomea apuna. Koska täydentävänä aineistona toimivan kyselylomakkeen avointen kysymysten vastaukset olivat hyvin niukkoja, toistivat haastatteluissa esiin nousseita näkökulmia tai joissakin tapauksissa keskittyivät lähinnä henkilöstön väliseen vuorovaikutukseen, kyselylomakkeiden vastauksia ei ole sisällytetty luvussa 4 käsiteltävään aineistoon. Keskitymme tässä artikkelissa aineiston ja tulosten esittelyssä siis erityisesti haastatteluaineistoon, jonka teemoittelussa olemme hyödyntäneet myös etnografisia havaintojamme.

\section{TULOKSET}

Tässä luvussa esittelemme asukkaiden, hoitajien ja esimiesten tutkimushaastatteluissa esittämiä käsityksiä ja kokemuksia siitä, mil- laista on ja voisi olla toimiva vanhuslähtöinen kieli ja vuorovaikutus hoitokontekstissa, tässä tapauksessa vanhainkodissa ja tehostetun palveluasumisen yksikössä. Myös yhden asukkaan haastattelussa mukana olleen omaisen näkemyksiä on nostettu joissain kohtaa esiin asukkaan näkökulmien rinnalle. On tärkeää huomata, että kielenkäyttäjien (ns. maallikkojen) tapa nimetä ja luokitella kielenilmiöitä ja vuorovaikutusta ei välttämättä vastaa kielentutkijoiden tapoja ymmärtää ja jäsentää kielen ja vuorovaikutuksen ilmiöitä (ks. esim. Preston, 2004). ${ }^{5}$ Niinpä esimerkiksi jotkin multimodaalisuuden ilmiöt tulevat aineistossamme esiin useissa eri kohdissa ja kytketään haastatteluissa keskenään erityyppisiin tilanteisiin tai vuorovaikutustavoitteisiin, mikä sinänsä on tärkeä osa kielikäsitysten diskursiivista analyysiä. Olemmekin jäsentäneet tulosten esittelyn pääosin haastatteluissa rakentuvien käsitteistysten mukaan. Näitä keskeisiä vanhuslähtöisen kielen ulottuvuuksia, joita haastatteluissa nousi esiin, ovat vuorovaikutuksen ja keskustelun laatu, määrä ja sävy (alaluku 4.1), puhuttelun ja nimeämisen tavat (alaluku 4.2), äidinkieli ja monikielisyys (alaluku 4.3) sekä kosketuksen ja muun multimodaalisen vuorovaikutuksen merkitys (alaluku 4.4). Analysoimme ja esittelemme seuraavaksi näitä kielen ulottuvuuksia eri osallistujaryhmien näkökulmista (asukkaat, hoitajat, esimiehet).

\subsection{Vuorovaikutuksen ja keskustelun laatu, määrä ja sävy}

Kaikissa haastatteluissa nousivat keskeisinä asioina esiin vuorovaikutuksen ja keskustelun määrä, laatu ja sävy sekä ongelmat. Asiaa myös kysyttiin haastatteluissa muun muassa

5 Tässä tutkimuksessa on kuitenkin syytä huomata, että vanhustyössä käytettävän kielen ja vuorovaikutuksen kysymykset olivat jollakin tapaa osalle haastateltavista tuttuja, sillä niitä oli käsitelty kunnan järjestämissä koulutustyöpajoissa. 
seuraavanlaisilla kysymyksillä: Millainen keskusteluilmapiiri täällä on mielestäsi? Onko sinulla sopivasti juttuseuraa? Oletko tyytyväinen siihen, mitä/miten sinulle puhutaan? Mistä haluaisit puhua? Kuunnellaanko sinua? Erityisesti asukkaat nostivat keskeiseksi keskustelun ja kuuntelun sekä kuulluksi tulemisen, kun taas hoitajat pitivät tärkeänä erityisesti kuuntelemista ja selkeää artikulaatiota. Aineistosta nousee siis esiin osin erilainen tarve vuorovaikutukseen. Toisaalta hoitajat kertoivat keskustelevansa asukkaiden kanssa paitsi hoitotoimenpiteistä ja voinnista myös säästä sekä arkisista ja menneistä asioista. Vanhustyön esimiehet puolestaan korostivat kielenkäytön ja vuorovaikutuksen ymmärrettävyyttä abstraktimmalla tasolla. Nämä näkökulmat tulivat esiin erityisesti heiltä itseltään, sillä heidän haastatteluissaan ei käytetty samaa haastattelurunkoa kuin hoitajilla ja asukkailla, vaan esimiehet saivat kertoa käsityksiään vanhustenhoidosta ja kielenkäytöstä vapaammin.

Asukkaat nostivat kaikkiaan haastatteluissa esiin erityisesti tarpeen enemmälle keskustelulle ja kuulluksi tulemiselle. He puhuvat keskustelusta enemmänkin sanan arkisessa, jokapäiväisessä merkityksessä, ja etenkin ne, joilla ei ollut muistisairautta, toivoivat esimerkiksi keskustelua myös omasta menneisyydestään:

\section{Esimerkki $1{ }^{6}$}

A3: [men] det där \#em\# nu är den \#m-\# att sku behöv- (0.9) prata mera (1.0)\#m- ö-\# (0.8) ha liksom (1.0) att dom sku få igång någon (.) någon sån hän (1.3) diskussioner

T2: just,

6 Esimerkeissä $\mathrm{A}=$ asukas, $\mathrm{T}=$ tutkija, $\mathrm{O}=$ omainen, $\mathrm{H}=$ hoitaja ja $\mathrm{E}=$ esimies, numerot kirjaimen perässä erottelevat yksilöitä toisistaan. Aineisto on litteroitu sanatarkasti (ks. Aineistonhallinnan käsikirja, litterointi). Litterointimerkit on selitetty liitteessä 1 . Lihavointi osoittaa huomion kohteena olevia kohtia.
O: [ja. ]

$\mathrm{A} 3$ : [om] nånting att $(0.3)$ att hur du var det förre hur hade du det som barn [och hur]

T2: [just, ]

A3: och hur och hur

T2: just, (0.4) just det.

\section{A3: men dom har int tid}

Kiintoisaa on, että esimerkissä 1 asukkaan toive keskustelusta näyttää kohdistuvan hoitajiin (men dom har int tid) eikä toisiin asukkaisiin. Tätä voi selittää se, että haastatteluissa tulevat esiin myös vuorovaikutuksen kielelliset haasteet ja rajoitukset, esimerkiksi kunkin oma äidinkieli ja kyky toimia toisella kotimaisella. Asukkaiden keskinäistä keskustelua saattoivat huomattavasti rajoittaa paitsi muistisairaudet myös yhteisen kielen puute (ks. lukua 4.3). Asukkaiden välillä oli myös muita henkilökohtaisia eroja sen suhteen, kuinka aktiivisesti he juttelivat ja pystyivät juttelemaan toisille asukkaille - esimerkiksi huonokuuloisuus, muistisairaus tai oma sosiaalisuus asetti rajoituksia vuorovaikutukselle (esim. A2: men så är här ju sådana (0.6) patienter som int hör nånting [...] men jag ändå talar med dom). Asukkaiden käsityksissä keskustelusta ja vuorovaikutuksesta korostuu paikoin myös sosiaalisen vuorovaikutuksen ja kognitiivisen toiminnan arvo itsessään. Esimerkiksi eräs asukkaista kertoi kaipaavansa aiemmin pidettyä tietovisaa.

Myös joissain hoitajien haastatteluissa nousivat esiin arkiset kuulumisten vaihdot sekä yhteiset, yleisissä tiloissa tapahtuvat keskustelut, uutisten jakamiset ja muistelutuokiot. Eräs hoitajista kertoi tällaisen juttelun ja vuorovaikutuksen olevan hoitoarjessa ihan normaalia, joskin tavallaan menevän jo pelkän hoitajan työnkuvan ulkopuolelle ( $\mathrm{H} 1: \mathrm{Ku}$ tunnetaan jo toisten kaa niin hyvin ni (0.3) [...] On niinku tosi läheinen sillä taval et mä enootavallaan@pelkkä@hoitaja). 
Muutkin hoitajat mainitsivat arkisten kuulumisten vaihdon ja esimerkiksi uutisista keskustelun asukkaiden kanssa tärkeänä osana vuorovaikutusta, mutta osalle heistä oli tärkeää säilyttää ammatillinen rooli ja vetää rajat sille, kenen arjesta keskustellaan $(\mathrm{H} 3: \mathrm{No}$ silloinmä pubun omast elämäst jos (0.4)@ kysyy@(0.5)Mut omaa elämää mä en sekota työelämään). Kenties hieman yllättävää oli, että kukaan hoitajista ei vedonnut kiireeseen syynä siihen, ettei ehtisi jutella asukkaiden kanssa. Päinvastoin useampi totesi, että aikaa vuorovaikutukseen kyllä on, ja eräs jopa kuvasi, että suurin osa työajasta menee asukkaiden kanssa "höpöttelyyn" - joskin tämä kytkeytyy erityisesti hoitotoimenpiteiden yhteydessä tapahtuvaan vuorovaikutukseen (H1: mut näitte asukkaiden kanssa kyl suurin os a päiväst menee siihen et höpötellään vaikka asukas ei välttämättä ite kykenis pubuun niin mä ainaki pubun heille koko aika ku tehään aamupesuja ja käydään vessassa ja näin).

Kiinnostavaa on, että tarve jutella ja keskustella saa erilaisia kuvauksia asukkailta ja hoitajilta. Asukkaiden keskustelutoiveet liittyvät arjen jakamiseen, oman viihtymisen lisäämiseen sekä omaan henkilökohtaiseen historiaan ja identiteettiin. Nämä teemat olivat asukkaille merkityksellisiä. Myös hoitajat puhuvat arkisesta kuulumisten vaihtamisesta, mutta heistä osa nostaa esiin ammatillisen roolinsa ja sen tuomat rajat vuorovaikutukselle. Lisäksi hoitajat puhuivat vuorovaikutuksesta erityisesti monikanavaisena ja hoitotyön sujuvoittamisen näkökulmasta (ks. tarkemmin lukua 4.4), kun taas asukkaat puhuivat enemmän keskustelun aiheista ja sisällöistä.

Vaikka esimiesten näkökulma vanhuslähtöiseen kieleen oli abstraktimpi, siinä voi

7 Tuloksiin vaikuttaa osaltaan se, että hoitajia haastateltiin muistisairaiden vanhusten yksikössä ja asukkaita puolestaan tehostetun palveluasumisen puolella - jälkimmäisessä asukkaat olivat selkeästi parempikuntoisia, vaikka osalla heistäkin oli muistisairaus. nähdä yhtymäkohtia sekä hoitajien että asukkaiden käsityksiin. Esimiesten haastatteluissa vanhuslähtöistä kieltä kuvattiin muun muassa käytännönläheiseksi ja ymmärrettäväksi, ja yhdellä heistä oli ajatus uudenlaisen kielen kehittämisestä:

\section{Esimerkki 2.}

E1: et hallinnon kieltä pystyttäs muuttamaan et mä näkisin et se on myös niinkun ymmärrettävämpää [...] jotta se niinku näkyis ja kaikessa niinku meijän eri viestinnän tasoissa et onko se sit meijän kotisivut vai vai onko se sitte miten me niinku virkamiehet puhutaan tai onko se sitte se miten lukee päätösasiakirjoissa

Esimiehet pitivät tärkeänä sitä, että keskeinen tieto välitettäisiin oikein ja että ymmärtäminen olisi mahdollista silloinkin, kun on vanha ja huonomuistinen. Eroa voi kuvata kielen funktioiden erolla: siinä missä asukkaat korostavat pikemminkin sosiaalisen vuorovaikutuksen funktiota, hoitajille ja esimiehille tärkeää on tiedon välittämisen ja kielen toiminnallisuuden funktio. Tämän voi ajatella liittyvän siihen, että asukkaiden ja hoitotyön ammattilaisten (tilanteiset) kontekstit eivät ole samat vaan perustavanlaatuisesti erilaiset: hoitajat ja esimiehet ovat töissä ja vastuussa toiminnastaan, kun taas asukkaat elävät arkeaan institutionaalisesti ohjatussa paikassa. Eroa on myös temporaalisessa ulottuvuudessa. Hoitajat ovat paikalla vain osan päivästä ja tällöin tietyt tehtävät pitää saada tehtyä, kun taas asukkaat ovat siellä koko ajan ja heidän aikaansa rytmittävät hoitajien ja insituution rytmit (ruokailu, hoitotoimenpiteet).

Keskeinen ero on myös kokemus vuorovaikutuksen sävystä hoitotyössä. Hoitajat korostivat omassa vuorovaikutuksessaan erityisesti rauhallisen ilmaisutavan tärkeyttä, ja yleisemmällä tasolla toivottiin kautta linjan ihmistä kunnioittavaa, asiallista vuorovaikutusta. 
Kuten aiemmassa tutkimuksessa on todettu, yksinkertaistetut ilmaukset ja selkokielisyys ovat yksi tärkeä tapa selkeyttää viestintää ja lisätä ymmärrystä (mm. Ryan, Spykerman \& Anas, 2005; Lindholm, 2012). Osa hoitajista nosti esiin juuri tällaisia keinoja määritellessään vanhusta huomioivaa kielenkäyttöä:

\section{Esimerkki 3.}

H4: Mutta (0.4) yleensä (-) (0.6) jos sitä näin ajattelee niin ensinnäkin rauhallisuus (0.7) toisena positiivisuus $(0.7)$ ja $(0.5)$ sellainen (1.5) asiallinen (0.5) Ei mitään (0.5) liian höpötystä eikä (0.4) eikä liian selitystä (0.9) käskevään sävyyn eikä

T1: Mmm. Mmm.

Esimerkin 3 hoitaja on juuri ennen katkelmaa maininnut, että keinot on valittava asukaskohtaisesti hoitajan henkilökohtasen ymmärryksen mukaan. Hän kuitenkin listaa myös useita tekijöitä, jotka hän käsittää vanhuksen huomioivaksi kielenkäytöksi: rauhallinen puhe, positiivisuus, asiallisuus eikä höpötystä tai käskyttämistä. Haastattelussa hoitaja korostaa myös äänensävyn merkitystä. Huutaminen tai äänen korottaminen voidaan kokea pelottavaksi, mutta sen sijaan rauhallinen puhe varmistaa sen, että muistisairas asukas pystyy kuuntelemaan myös viestin sisältöä, ei vain äänensävyä: Koska jos sä hitaasti ja rauballisesti ja selvästi pubut niin (0.4) se asiakas rentoutuu siinä (0.6) elikkä se kuunteleesun pubetta (0.3) eikä pelkää sellaista (0.5) @ä̈̈ntä@(0.4).

Myös toinen haastatelluista esimiehistä puhui kielenkäytön kohdentamisesta ihmisten taustan ja historian mukaan esimerkiksi niin, että osaa valita "kirjakielisen" puhetavan sellaiselle, joka siihen on tottunut, ja toisentyyppisen puhetavan "maanviljelijälle”. Esimies siis tuo selvästi esiin käsityksen, että eri yhteiskuntaluokkia tai ammattiryh- miä edustavia ihmisiä on syytä puhutella eri tavoin. Tässä nousee esiin laajemmin kielenkäyttöä säätelevä kieli-ideologinen periaate, jossa kielellisen tyylin valinta sidotaan yhteiskunnalliseen asemaan ja kontekstiin - myös vanhustyössä. Selkeästä viestinnästä tai tietylle ihmiselle yksilöllisesti kohdennetusta puhetavasta ei myöskään vaikuttanut olevan kyse, kun haastatteluissa puhuttiin ei-toivotusta tavasta puhua kuin lapselle (vrt. "vanhuspuhe" luvussa 2.2). Haastatteluissa, joissa tämänkaltainen "lapsenkielisyys" nostettiin esiin, viitattiin enimmäkseen sävyyn eikä vaikkapa sananvalintoihin, toistoon tai lauserakenteisiin. Tämä käy ilmi esimerkistä 4 , jossa hoitaja kertoo, että aikuisille täytyy puhua aikuiseen ääneen:

\section{Esimerkki 4.}

H2: Mm ei enää mut täs yhes vaihees (.) neljä viis vuotta sitte ni tääl oli yks joka (0.3) puhu (0.5) näille ku puhuis lapsille. Ja se mua niinku ärsyttää ihan jumalattomasti.

T2: Muistaksä millasia ilmauksia ne,

H2: Siis ihan niinku yleisesti (0.8) et mua on opetettu et nää- nää on aikuisii ihmisii näille puhu- puhutaan aikuiseen ääneen ja,

T2: Mmm.

H2: öö se on alentavaa jopa puhuu (1.2) ku ne olis jotain pienii (1.2) [lapsia.

Sama ei-toivottu puhetapa nousi esiin myös omaisen kommenteissa, joka toi esiin sen, että sekä omainen että asukas voivat kokea tällaisen puhuttelun alentavana:

\section{Esimerkki 5.}

O: mutta se mitä (0.7) mitä mua häiritsee on tietysti että (0.9) ei kaikki mutta (0.4) toiset niinku puhuu niinku (0.4) pikkulapsille

T2: joo. (.) just, 
$O$ : ja vauvoille ja semmosta kieli ja $(0.5)$ ja ja taputtavat ja voi voi sinä pikkunen ja tämmöstä se

A3: jo nej nej det

$O$ : se ee se niinkun ei

A3: (--) det det (0.6) var och en har sitt arbete här så (2.3) (sängarska är bädda) och den den är ju bättre redan nu (1.4) men såg vi ju tv

[katkelma poistettu]

$\mathrm{O}$ : jollain tavalla pitäs puhua sille ihmisille niin että hän on täys(1.3)vertainen ettei hän o mikää pikkulapsi et voi voi että@kuinka sinä nyt voit täällä@tai tom- tommonen

T2: $\mathrm{mm}$,

$\mathrm{O}$ : sävy

Esimerkit valaisevat vuorovaikutuksen sävyn monifunktionaalisuutta. Sen, mikä useimpien hoitajien näkökulmasta koettiin hoivakielelle ominaisena selkeytenä ja selkokielisyytenä, saattoi osa asukkaista ja omaisista - ja jotkut hoitajatkin (esimerkki 4) - kokea alentavana, esimerkiksi "lapsenkielisenä" puhetapana. Tämäkin liittyy erilaiseen orientaatioon vuorovaikutuksessa ja keskustelijoiden keskinäisiin suhteisiin: hoitajat ovat töissä ja hoitovastuussa, asukkaat ovat (hoiva)kodissa elämässä arkeaan, jossa keskustelukykyisin henkilö on usein hoitaja.

\subsection{Pubuttelun ja nimeämisen tavat}

Yksi vanhustyön vuorovaikutuksen keskeinen ilmiö on se, miten asukkaat ja hoitajat puhuttelevat tai nimittävät toisiaan. Puhuttelu liitetään yleisesti kohteliaaseen käytökseen, ja puhuttelulla voidaan osoittaa monenlaisia sosiaalisia merkityksiä: kunnioitusta, sosiaalista etäisyyttä tai läheisyyttä, tuttavallisuutta tai esimerkiksi valta-asemaa; lisäksi se vaikuttaa vuorovaikutuksen onnistuneisuuteen ( $\mathrm{ks}$.
Isosävi \& Lappalainen, 2015, s. 9, 13). Muun muassa teitittelyä on perinteisesti pidetty Suomessa tärkeänä erityisesti asiakastilanteissa ja esimerkiksi eläkeikäisiä puhuteltaessa, ja iäkkään henkilön teitittelyä pidetään Suomessa yleisesti kunnioittavana ja arvostusta osoittavana (Lappalainen, 2016). Lappalaisen (mt.) mukaan tuoreehko kyselytutkimus kuitenkin osoittaa, että nykyisin iäkkäät itse pitävät usein teitittelyä kiusallisena sekä turhan muodollisena ja etäisenä.

Omassa tutkimuksessamme puhuttelusta kysyttiin suoraan haastattelussa sekä hoitajilta että asukkailta. Hoitajat pitivät puhutteluun liittyviä valintoja tärkeänä, kun taas joillekin asukkaille sinuttelu tuntui olevan itsestään selvä käytänne. Hoitajat nostivat esiin lisäksi nimeämisen kysymyksiä, esimerkiksi sen, puhutaanko vanhuksesta etunimellä. Pääosin hoitajat kertoivat sinuttelevansa asukkaita mutta esiin tuli myös se, että teitittelyä käytetään, kun on kyse uudesta asukkaasta. Tämä on linjassa sen kanssa, mitä laajassa kyselytutkimuksessa havaittiin: Lappalaisen (2015, s. 81) mukaan tärkeimmät syyt teititellä olivat puhuteltavan korkea ikä ja tuntemattomuus. Hoitajista muutama kertoi haastatteluissa, miten uudet asukkaat kuitenkin saattavat reagoida teitittelyyn. Yksi hoitaja kuvasi tilannetta näin:

Esimerkki 6.

T2: Mites sitte tota (0.4) Sinutteleks sä? (.) Mä kuulin kyl tossa \$äsken huomasin että sä (.) puhut ihan nimellä\$ (0.4) sinutellen niinku (1.4)

H3: Kyyyllä (0.3) sinuttelen aina (.) (näitä) meidän vanhoja. (0.8) Näitä ketä on ollu täällä aina. (0.6) Mut sillon ku tulee @ uus@ihmine niin siinä alussa (0.3) Mut@tosi moni vanhus@ sanoo että minä en ole mikään @te.@ (1.0)Minun nimeni on tämä.

T2: Joo. (1.7) 
H3: Se lähtee yleensä sielt vanhukselt se (0.9) T2: Nii se on varmaan (0.3) No (0.5) Jos yrittää itse asettuu [siihe samaan asemaan H3: [Esimerkiks (intervallit?) (0.7) tietyt niin silloin (1.0) (.) jos teitittelee niin ne saattaa (.) vanhukset rupee nauraa että $(0.5)$ en minä ole mikään herra tai rouva tai tällanen vaan minun nimeni on tämä. (0.5)

T2: Joo. (.) Ne sanoo sit etunimen yleensä? H3:Kyllä

T2: Joo.

Esiin nousi myös käsitys, että teititellä kuuluu ylipäätään vanhempia ihmisiä ( $\mathrm{H} 1$ : Ja teitittelin kun tänne taloon tulin kun on vanhuksia kaikki). Asukkaat eivät kuitenkaan halunneet tulla teititellyiksi vaan kuvasivat teitittelyä viralliseksi ja vanhanaikaiseksi. ${ }^{8}$ Sen sijaan he toivoivat sinuttelua ja etunimellä puhuttelua. Esimerkistä 7 käy ilmi, että etunimellä puhuttelu on asukkaan mukaan tavallista ja että teitittelyn lisäksi sukunimen käyttö nähdään liian humoristisena tai virallisena.

\section{Esimerkki 7.}

T3: niihän ne yleensä on (2.2) no mites täällä ihmiset puhuu sitten ku meitä taas kiinnostaa se kielen käyttö että (.) miten täällä puhutellaan että teititelläänkö tai [sinutellaanko ]

A1: [no ei varmana]

T3: @\$ei varmana teititellä\$@

[katkelma poistettu]

T3: m- sielä vaa (0.3) miten sä haluaisit että sinua puhutellaan iha sinuttelu ja (0.4) etunimeltä vai

A1: joojoo. etunimeltä

T3: joo. (1.3) puhutellaanks täällä ketään

$8 Y$ Yksi asukas tosin mainitsi, että jotkut asukkaat myös toivovat teitittelyä. sukunimillä

(1.7)

A1: no en oikeen oo kuullu

T3: joo.

A1: no jos ei joku tee vitsiä ni

T3: nii just

[katkelma poistettu]

A1: juu ei tääl oo mitään virallista joku voi olla mut ei mul o em- ei mu- (1.2) ei minun (1.4) tuttavapiiri ny ees ku oo mitää semmosia virallisia ihmisiä

Jotkut asukkaat erityisesti toivoivat itseään puhuteltavan etunimeltä:

Esimerkki 8.

T1: mitenkäs työ (.) tykkäätte että teitä puhutellaan onko se hyvä jos omalla nimellä sanot että Vieno vai (.) rouva vai (.) mikä se ois hyvä

\section{A5: se Vieno on kaikkein läheisin}

T1: nii ju- =

\section{A5: =en mie koskaa missään rouvan asemas} ollu (et)

Kyse ei esimerkissä 8 ole vain hoitajan ja asukkaan välisestä vuorovaikutuksesta, vaan myös asukkaan identiteetistä ja henkilöhistoriasta: kuka on ollut ja mitä haluaa pitää mukanaan myös tässä uudessa hoitokodin institutionaalisessa kontekstissa? Myös hoitajien kertoman mukaan puhuttelussa käytössä on yleensä etunimi, sekä asukkaista että hoitajista. Hoitajien mukaan kuitenkin asukkaista ne, jotka eivät muista hoitajien etunimiä, joko sinuttelevat tai puhuttelevat työntekijöitä hoitajiksi.

Sen lisäksi, että asukkaat ja hoitajat kertoivat siitä, miten puhuttelu arjen vuorovaikutuksessa toimii, hoitajien haastatteluissa nousi esiin eksplisiittisiä sääntöjä, joista on keskusteltu henkilökunnan kesken. On esimerkiksi sovittu, että asukkaista ei käytetä tietynlaisia lempinimiä: 


\section{Esimerkki 9.}

T2: Njoo. (.) No nii. (1.0) Sitte tota sellane tärkee asia jos joka meitä kiinnostaa on se että (1.1) Mä e- nyt ei oo pelkästään kyse@susta@ja asukkaista vaan niinku yleisesti nii ooks sä tyytyväinen siihen et miten (0.6) asukkaille puhutaan (0.5) noi yleis-tai miten@niistä@puhutaan tai miten niille (0.4) miten puhutellaan (1.7)

H3:Nno (2.2) Tällä hetkellä oon koska siihen on tullu parannus (.) Täytyy myöntää että on ollu kyllä (0.4) joitain ihmisii joskus jotka (0.7) käyttää sellasta kieltä että siitä voi huomauttaa (0.8)

T2: Joo. Mi- millast kieltä se on? (1.6) [Ollu sit jos sitä on ollu

H3: [Nno (.) siis esimerkiks joku (1.0) lempinimi mikä ei ole tämän ihmisen lempinimi. (0.3)

T2: Okei.

H3: Esimerkiksi nii se se on sellain mistä on huomautettu että tätä ei käytetä näin $(0.5)$

T2: Joo. (0.4) Joo.

Yhden hoitajan (H5) haastattelusta käy myös ilmi, että hoitajia on ohjeistettu käyttämään itsestään sukunimiä, joskaan tätä ohjeistusta ei noudateta. Perusteluna on hoitajan mukaan ollut se, että kyseessä on ammattirooli ja että etunimen käyttö olisi niin @benkilökohtasta@.Hoitaja myös toteaa haastattelussa, että ohjeistus tuntuu hassulta, kun samaan aikaan korostetaan kodinomaisuutta. Ohjeistuksen mukainen puhuttelu sukunimellä kytkeytyy siis ajatukseen ammattiroolista, mutta hoitaja näkee tässä ristiriidan sen suhteen, että samaan aikaan pitäisi olla toimijana kodinomaisessa ympäristössä. Näin institutionaalinen käsitys sopivasta puhuttelutavasta ja arkinen käsitys kotiympäristöön sopivista puhuttelutavoista törmäävät.

Kun asukkaita ei yksilöidä etunimin, hoita- jat käyttivät heistä yleisnimitystä asukas:

Esimerkki 10.

T1: entäs totaa (.) onks sitten ollu (.) siitä keskustelua (.) joko hoitajien kesken tai sitten yhessä vanhusten ja omaisten kans että miten puhutellaan näitä teiän asukkaita täällä (. ) toivooks ne että nimellä vai rouvitellaan vai vanhus [vai seniori ] H5:

[siitä ei oo]

koskaan ollu puhetta

T1: joo

H5:et (.) mut jotenkin niinkun ((rykäisee)) mie ite kyllä alotan aina sen kun tulee uus ihminen että (.) että tota niin mä teitittelen mut sit se niinku pikkuhiljaa siirtyy siitä (.) sinutteluun

T: $\mathrm{mm}($.

T1: entäs sitten muuten käytätkö s- onko he asukkaita vai vanhuksii vai

\section{H5: asukkaita}

T: joo

H5: mm ne on meiän asukkaita

T: joo

Viitatessaan asukkaisiin hoitajat käyttivät haastatteluissa etunimien ja sanojen asukas ja asiakas lisäksi myös sanoja vanhus, mummo ja ibminen. Esimiesten näkökulmasta erityisesti vanhustyön sanasto kaipaisi muutosta: byrokraattisen ja institutionaalisen kielen ilmauksia voisi korvata sellaisilla arkisemmilla sanoilla kuin koti, huusholli tai vierelläkulkija (hoitajasta). Esimiesten käsityksissä korostui heidän oma työympäristönsä, sillä erityisesti he puhuivat hallintotekstien ymmärrettävyydestä vanhusten ja yleisemminkin kuntalaisten näkökulmasta. Käytännön hoitotyön arjessa näyttäisi kuitenkin siltä, että esimerkiksi ammattinimike ei välttämättä ole ongelma, koska sen usein korvaa kunkin ihmisen oma (etu)nimi. 


\section{3 Äidinkieli ja monikielisyys}

Tutkimusympäristönä olevat hoitoyksiköt olivat kaksikielisiä, ja asukkaiden äidinkielenä oli joko suomi tai ruotsi. Haastatteluissa kävi ilmi, että osa asukkaista on yksikielisiä eivätkä kaikki asukkaat välttämättä siis pysty keskinäiseen suulliseen vuorovaikutukseen. Hoitajat taas olivat valtaosin äidinkieleltään suomenkielisiä mutta muutama oli ruotsinkielinen ja yksi vironkielinen. Kaikki hoitajat osasivat suomea, kun taas ruotsin kielen taito hoitajien kertoman mukaan vaihteli sujuvasta vähäiseen. Se, että ympäristö on kaksikielinen, tuli haastatteluissa esiin eri tavoin. Näitä olivat mm. äidinkielen merkitys, maallikkotulkkaus ja ymmärrysongelmat.

Kielten käytöstä ja kaksikielisyydestä puhuttaessa hoitajat ottivat lähes poikkeuksetta esiin äidinkielen arvon ja merkityksen siten, että he mainitsivat pitävänsä tärkeänä puhua kullekin asukkaalle tämän omalla äidinkielellä. Esimerkiksi yksi hoitaja (H1) kuvasi ajatuksiaan kielen valinnasta näin: Mutjos on niinku ruotsinkielinen (0.6) ibminen niinku et se on sen äidinkieli nikylmä yritän pubuu parhaani mukaan ruotsia. Koska mäki tykkään et mulle pubuttas sit suomea kun mä oon vanha. Hoitajien kielitietoisuus oli siis tältä osin vahvaa ja kielikäsitys äidinkielen arvoa korostava riippumatta heidän omasta äidinkielestään tai omista kieliresursseistaan.

Kaksikielisyys voi toimia myös vuorovaikutuksen ja hoitotyön resurssina: esimerkiksi resursseilla leikittely ja asukkaiden osallistaminen pyytämällä käännöksiä toimivat arjen muistijumppana. Hoitajat vaikuttivat olevan tietoisia kaksikielisyyden myönteisestä vaikutuksesta muistiin, kuten esimerkissä 11, joka on kaksikielisen hoitajan haastattelusta.

\section{Esimerkki 11.}

H3:En (.) ei var- ei ehkä o jos ihan rehellisest sanotaan ei o (0.8) Mut taas ruotsin kielel voi leikkii silläviisii tota noin että kun (0.9) ettää kysyy että @mitäs tää sana tarkottaa?@(0.7) Että sielt tulee se suomi että (.) silläviisii pääsee vähän niinko se muistaminenkii totanoi $(0.7)$ ja sitte voi joskus olla että nii että @mitäs mikäs tää nyt oli vaikka makkarakeitto mikäs se oli ruotsiks@ ni (0.3) sitte (.) täält tulee se (0.8) joka ruotsin kielel niin (0.4)@ aaa@(0.3)

T2: Aaa [se onki hyvä ]

H3: [Et sitä voi vähä] käyttää täs hoitotyössäki niinko (1.2)

T2: Nii [et se ]

H3: [Sillviisii.]

T2: Se voi olla niinku samalla $\$ \mathrm{t}(\mathrm{h})$ avalla etu $\$$ kun siis (0.2) [ihan sama (--)

H3: $\quad$ SSe on mun mielestäse on $(-)$ ] T2: siis (0.3) sehän on (0.2) kaikissa ikävaiheis mutta se (0.5) just että se on niinku aivoille kauheen terveellistä [että $(-)$ ]

$\mathrm{H} 3$ : [Nii et se]

on vähä sellasta muistijumppaa (.) tota että $(0.5)$

Suomen- ja vironkieliset kuitenkin kokivat toisella kotimaisella toimimisen usein myös haastavaksi, ja ainakin satunnaiset ymmärrysongelmat mainittiin. Tähän oli hoitotyön arjessa kehitelty erilaisia ratkaisuja. Vironkielisen hoitajan ruotsin kielen taito oli hänen kertomansa mukaan sen verran rajoittunut, että hän sanoi kyllä jotenkuten ymmärtävänsä puhuttua kieltä ja hyödyntävänsä tarvittaessa myös vuorovaikutusvihjeitä: Mutta sitten kuin tulee pitemmät (0.7) niin pitää vaan äänensävystä (0.5) ymmärtää.

Asukkaat olivat pääosin yksikielisiä, ja heidän toisen kotimaisen kielen taitonsa vaihteli runsaasti. Yksi haastateltava ruotsinkielinen asukas pystyi toimimaan molemmilla kielillä ja sanoi puhuvansa suomenkielisille suomea ja ruotsinkielisille ruotsia. Muut yksikieliset asukkaat toivat esiin ymmärrysongelmat 
asukkaiden keskinäisessä vuorovaikutuksessa. Useimmat sanoivat ymmärtävänsä toista kotimaista, mutta eivät pystyneet puhumaan sitä, mikä tulee ilmi erään asukkaan (A4) kommentissa: mut sitte ne jä̈ vähä vajaaks kun (.) ei o muuta ku sen varassa et no siebän osaatki suomee ku öö ruotsii ku sanon ybtäkkii pari kolme sanaa ni se o liian (vaativaa). Joillain suomenkielisillä asukkailla oli käsitys, että ruotsinkieliset asukkaat ovat lähes poikkeuksetta kaksikielisiä (A1: mut yhdeksänkyt prosenttia niistä osaa sujuvaa suomee) ja että kieliongelmat johtuvat heidän omasta puutteellisesta ruotsin kielen taidostaan (A1: kyl mä nyt ymmärrän mitä toiset pubuu mut emmä (.) emmä (1.7) emmä mitää lauseita osaa pubua). Tämä käsitys toisten kielitaidosta ei kuitenkaan pitänyt paikkaansa, sillä vain osa ruotsinkielisistä asukkaista pystyi toimimaan kahdella kielellä.

Suomenkieliset asukkaat eivät maininneet ymmärrysongelmista hoitajien kanssa, mutta tämän nostivat esiin ruotsinkieliset asukkaat:

\section{Esimerkki 12.}

T3: juu juu. (2.0) öö förstår man allt (0.9) vad du säger o

A2: no vad ska jag säga (0.4) nu är det en där sköterska som int förstår riktigt vad jag menar

T3: ookei.

A2: fast hör jag försöker

T3: ju,

A2: men dom ända sköterskor säger att dom förstår int nog vad jag säger

Myöskään suomenkieliset hoitajat eivät nähneet hoitajien keskinäistä vuorovaikutusta ongelmallisena, mutta ruotsinkieliset hoitajat totesivat, että he joutuvat kirjoittamaan raportteja suomeksi eli eivät voi tehdä sitä äidinkielellään. Kävi myös ilmi, että koska kirjoitetut raportit tehdään suomeksi, ruot- sinkielisillä asukkailla tai heidän omaisillaan ei välttämättä ole pääsyä asukkaita koskeviin tietoihin omalla äidinkielellään.

Haastatteluissa tuli esiin myös maallikkotulkkaus yhtenä rutiininomaisena kielikäytänteenä, jolla kaksikielisessä yhteisössä toimitaan. Tulkkausta tarvitaan sekä asukkaiden kesken että toisinaan hoitotoimenpiteissä, silloin kun hoitajan ja asukkaan vuorovaikutus ei eri äidinkielten vuoksi suju. Esimerkissä 13 tutkija kysyy kaksikielisyydestä ja siitä, miltä eri äidinkielet mahtavat asukkaista tuntua. Vaikka hoitaja toteaa osan asukkaista olevan aika hyvii tulkkei, vastauksesta (ja etenkin sen alkamisesta mut-partikkelilla) voi päätellä, että tilanne ei ehkä kaikilta osin ole hyvä mutta toisaalta hän pitää tulkkaamista sekä hyvänä ajanvietteenä että myöhemmin haastattelussa muistin harjoittamisena.

\section{Esimerkki 13.}

T2: Joo (0.5) \$Kuulostaa hyvältä.\$ (0.3) Mä jotenki tossa (.) rupesin ite miettiin sitä niinku (0.3) tietysti ku kuultiin kuinka (0.3) paljon tääl on ruotsinkielisii asukkaita ja kuinka paljon suomenkielisii tai kakskielisii ja sitte mä rupesin miettii että mitenhän se (1.8) niinku (0.6) miltä se tuntuu (0.3) asukkaasta (0.3) että (0.3)

$\mathrm{H}$ : Mut nää on aika hyvi- (.) toiset on aika hyvii tulkkei myös että ne osaa niinko (0.4) kääntää et ne puhuu ruotsia ja sitte (0.3) ne kääntää sitä $(0.6)$ niinko $(0.3)$ et (0.4) se on

\section{[ajanvietettäki vähäsen]}

T2: [Niinku tulkkaa toisiaan]

$\mathrm{H}$ : vähäsen niinko että $(0.4)$

T2: Joo

$\mathrm{H}$ : Joissain et siis mehän voidaan kysyy että jos kattoo telkkarista jotain niin et $(0.3)$ @mitäs se sana tarkottaa@(0.7)ni (0.5) \$kyllä se sieltä useimmiten tulee sieltä\$ [totanoi]

T2: [Niijust] 
H: Ja sit ne kääntää sen suomeks (.) et se tarkottaa@sitä@(0.7)

T2: Niijust

$\mathrm{H}$ : Et se on vähä sellai leikki (0.2)

Kriittisemmin kaksikielisyyden toimivuuteen suhtautuvat tehostetun asumisen puolella tehdyssä haastattelussa asukas ja hänen omaisensa. He kertovat hyvin seikkaperäisesti haastattelussa asukkaiden keskinäisestä vuorovaikutuksesta, jota äidinkielen ja toisen kotimaisen kielen taidot hankaloittavat mutta jota omaisen rutiininomainen maallikkotulkkaus ilmeisesti helpottaa. Haastattelussa syntyy vaikutelma asukkaiden välisistä lämpimistä sosiaalisista suhteista, joita rajoittavat eniten erilaiset kielitaidot ja institutionaalisen tuen eli säännöllisen tulkkauksen puute. Esimerkki 14 tuo terävästi esiin sen, millaisia käytännön vuorovaikutuksen ja siten hyvinvoinnin ongelmia kaksi- ja monikielisyys voivat aiheuttaa vanhustyössä ja vanhusten arjessa: kaksi- tai monikielinen konteksti ei tee asukkaista kaksi- ja monikielisiä. Sillä, miten erikieliset asukkaat voivat kommunikoida keskenään ja miten esimerkiksi tulkkaus toimii, on merkitystä erityisesti asukkaiden osallisuuden ja kuulumisen kannalta (ks. Kinnunen, 2015, s. 316).

\section{Esimerkki 14.}

O: så hon har mycket att berätta (0.5) och hon är ju gammal nu (0.4) och dom sitter bredvid varandra dom Ann-Marie och Tyyne där (0.6) dag ut och dag in (.) och kan int prata med varandra

T2: okei,

O: och hon kan int finska och Tyyne kan int svenska $(0.4)$ och det bara går int (0.4) så dom sitter tysta med var sin tidning och läser

A3: nog förstår jag finska men när (-) Tyyne kan när jag pratar svenska så vet int Tyyne nånting
T2: $\mathrm{mhm}$,

A3: det är bara det

O: int förstår du heller vad hon säger (.) om int jag översätter

A3: no nu ee- en stor del föstår jag

T2: okei, (.) det skulle (0.5) skulle vara nån som (.) tolkar (0.4) där

$\mathrm{O}:$ [joo.]

A3: [joo.] det finns int här nu såna

Myös esimiehet korostivat kaksikielisyyden ja oman äidinkielen merkitystä erityisesti ihmisen vanhetessa: eli se kakskielisyys on tosi tärkee (.) tosi? tärkee asia (.) koska just se äidinkielen merkityshän nousee erityisesti sit mitä vanhemmaks sä meet ja jos tulee sitä? muistisairauttaja muuta (E1). Esimiesten näkökulmasta kaksikieliset palvelut on tuotettu kunnassa hyvin, joskin näkemys painottui erityisesti hallinnolliseen kaksikielisyyteen sekä palveluiden tarjoamiseen kahdella kielellä, ts. kaksikielisyyden toteuttamiseen lain tarkoittamalla tavalla. Siitä, miten hyvin kaksikielisyys toteutuu vanhustyön arjessa, esimiehillä ei ollut täsmällistä tietoa. He olivat kuitenkin tietoisia siitä, että kielivalikoima ja -tilanne voivat tulevaisuudessa olla entistä monimuotoisempia, kun maahanmuuttajataustaisten ja erikielisten vanhusten määrä hoidossa kasvaa.

\subsection{Kosketuksen ja muun multimodaalisen vuorovaikutuksen merkitys}

Multimodaalisen vuorovaikutuksen merkitystä erityisesti muistisairaiden vanhusten kohdalla on korostettu myös aiemmassa tutkimuskirjallisuudessa (mm. Hamilton, 2008; Lindholm, 2012). Myös omassa aineistossamme kosketuksen ja muiden puhumista täydentävien tai korvaavien vuorovaikutuskeinojen merkitystä pidetään hoitajien haastattelujen perusteella tärkeänä. Asukkaiden haastat- 
teluissa sanattoman viestinnän merkitys ei noussut esiin, lukuun ottamatta yhden asukkaan mainintaa, että hän ei pidä siitä, että häntä kosketetaan.

Hoitajien haastatteluissa nousee selvästi esiin heidän vuorovaikutuksensa muistisairaiden asukkaiden kanssa, jolloin korostuu monikanavainen ja sanaton viestintä. Hoitajat pitivät sanatonta viestintää tärkeänä etenkin silloin kun kyse on muistisairaasta asukkaasta, kuten näkyy esimerkistä 15 .

\section{Esimerkki 15.}

T3: Nii. (.) Kyllä kyllä. (0.6) Onks siinä mitään ongelmia siinä (0.8) just jos miettii että on näitä (0.4) muistisairaita että (.) ymmärtääkö ne aina esimerkiks niitä hoitotoimenpiteitä?

H1: No totah (2.9) On siis silleen et (1.2) tä (.) ku on joku tietty muistisairaus nii ei
ymmärrä sitä niinkun puhetta

T3: Joo

H1:Taikka ymmärtäis mutta se kroppa ei enää toimi sen niinku mukaan

T3: Niijust. Mm.

H1:Nii sit niinku näyttää käsillä niinku elekielillä

T3: $\mathrm{mmm}$

H1:ja ilmeillä et mitä tehdään. Pestään kasvot niin mä näytän niinku aina

T3: Mm joo

H1:kädellä niinku omaan naamani et mitä tehään. Kerran yks mummo rupes sit mun naamaa peseen ku mä näytin niinku [naamanpesua

T3: [heh heh

H1:niin sehän oli fiksusti ajateltu että (0.3) mä lu-

T3: \$sun naamaa\$

H1:\$tarkottasin et mun naama [pitää pestä\$] T3: [he he \$Just joo\$

$\mathrm{H} 1$ :\$Sit mä rupesin nauraa ja sanoin et eiku sun $\$$ ja näytin niinku näin (.) sen naamaa niin sit se niinku tajus ja rupes nauraan. T3: Niinnii. Joo.

$\mathrm{H1}$ :Et on tosi hauskoja tilanteita välillä.

T3: Niin kyllä kyllä. Mm.

H1:Ja sitte (1.5) just niinku aina sanon että vasemmalle ja näytän kädellä niinku samalla et vasemmalle et siin tulee niinku se (0.6) Sana tulee siinä se (0.3) keskustelu ja sit kuitenki niinku elekielellä. Mut yleensä se elekieli niinku tosi hyvin (0.5) auttaa

T3: Joo. (0.4) Kyllä.

Esimerkissä hoitaja kuvaa ensinnäkin, miksi sanatonta viestintää tarvitaan ( $k u$ on joku tietty muistisairaus nii ei ymmärrä sitä niinkun pubetta), ja toiseksi, miten sana ja viittoma toimivat yhdessä toisiaan täydentäen (Ja sitte (1.5) justniinku aina sanon että vasemmalle ja näytän kädellä niinku samalla et vasemmalle). Esimerkki kuvaa hyvin sitä, miten vuorovaikutus jäsentää hoitajan näkökulmasta nimenomaan toimintaa, kuten kasvojen pesua tai liikkumista. Lisäksi siitä näkyy hyvin, miten vastavuoroisessa vuorovaikutuksessa hoitaja muokkaa viestintäänsä vanhuksen toiminnan pohjalta (Kerran yks mummo rupes sit mun naamaa pesee ku mä näytin niinku naamanpesua). Ymmärtämisongelmissa huumori voi edesauttaa hoitotoimenpiteiden sujuvuutta ja luoda solidaarisuutta vuorovaikutustilanteeseen (ks. myös Heinemann, 2009; Marsden \& Holmes, 2014). Aineiston perusteella on niin, että vuorovaikutus liittyy hoitajien näkökulmasta etenkin heidän oman työnsä tavoitteelliseen toimintaan, kuten hoitotoimenpiteisiin.

Erityisesti hoitajien haastatteluissa kerrottiin myös kosketuksen ja esimerkiksi laulamisen merkityksestä. Tämä liittyi erityisesti vuorovaikutuksen mukauttamiseen muistisairaan asukkaan aistimaailmaan. Koskettaminen on muistisairaiden kohdalla tärkeää - joskin hoitajien haastatteluissa nousi selkeästi esiin, että 
"oikein" koskettaminen on (ammatillinen) vuorovaikutustaito, joka on erityisen tärkeä muistisairaita rauhoitettaessa: ja sanotaan et ei se aggressivisuuska lopu ku veittellä leikaten vaikka siiben meniski niinku (0.6) sen ibmisen luo mut et vähän aikaa kun osaat jutella ja (0.4) kosketella (0.2) seki pitää muuten oppia että ketä kosketellaan ja millä tavalla kosketellaan (H5).

Hoitajista osa otti lisäksi erikseen esiin laulamisen osana hoitotyön vuorovaikutusta ja toiminnan sujuvoittamista. Laulaminen tukee ja auttaa hoitotoimenpiteissä. Esimerkiksi yksi hoitaja toteaa: Yks me saadaan toimimaan jopa paremmin jos sille laulaa. Sama toiminnan onnistuneisuutta korostava merkitys tulee esiin esimerkissä 16 .

\section{Esimerkki 16.}

H3: Ja sit meil on sellassii asukkait että (0.3) jotka $(0.7)$ ei niin hirveesti niinku puhu (0.4) jotka on niinko sanotaan sänkypotilaita ni (.) mut niiden kans taas laulelen. ((naurahtaa))

T2: Nii tää laulamine on

H3: Joo

T2: sem- mä oon siis kuullu [siitä että]

H3: [Kyllä ] (0.6)

T2: se on ilmeisesti semmonen

H3: Se vetää aika aika monelle niinko silläviisii saa niinko (0.5) luotuu niinko sellasen (0.5) hyvän (0.4) hauskan jutun ja sitte toimii sy-ruokailu ja sitte toimii pukemine ja sitte toimii peseminenki jja (0.6) tällane nii

T2: Mikähän siin o- (.) mistäs se su- (0.9)

H3:Kaikkihan rakastaa musiikkii (.) melkeen.

Hoitaja kertoo esimerkin alussa, että laulaminen toimii puhetta korvaavana vuorovaikutuskanavana sellaisten potilaiden kanssa, jotka eivät enää pysty kielelliseen kommunikaatioon. Hoitaja ottaa myös esille laulamisen merkityksen hoitotoimenpiteiden sujuvoit- tamisessa. Samassa haastattelussa hän kertoo myös, että tuttujen laulujen laulaminen yhdessä voi olla osa vuorovaikutusta ja yhteistä tekemistä (meil on ollu (0.2) sellassii laului mitä on joka ikinen päivä. (1.1) että dementikkokin oppii (0.2) muistamaan sanoja (0.4) ja sitten ku alottaa sen (0.3) niin hän jatkaa). Vastaavia esimerkkejä tuli esiin myös muiden hoitajien haastatteluissa. Kokemus oli opettanut hoitajille, miten musiikki ja erityisesti laulaminen voivat sujuvoittaa hoitotilanteita ja helpottaa yhteistyötä. Laulaminen myös auttoi muistisairaita olemaan vuorovaikutuksessa muiden kanssa. Tämän havaitsimme konkreettisesti myös itse kenttätöiden lopuksi järjestämässämme lauluhetkessä: monet asukkaat, jotka olivat havaintojemme perusteella olleet hiljaisia, jopa puhumattomia, aktivoituivat laulamaan, kommentoimaan lauluja ja esittämään laulutoiveitaan. Musiikki kannatteli vuorovaikutusta ja tuki puhekyvykkyyttä.

\section{LOPUKSI}

Tässä artikkelissa olemme tarkastelleet, millaista on vanhuslähtöinen kieli eli hyvä ja vanhuksia osallistava kielenkäyttö ja vuorovaikutus vanhainkodissa asukkaiden, hoitajien ja esimiesten näkökulmasta. Kootusti voi sanoa, että vaikka näiden kolmen kielenkäyttäjäryhmän käsitykset vanhuslähtöisestä kielestä hoitokotien arjessa eroavat jonkin verran toisistaan, niissä toisaalta toistuvat samat teemat ja toiveet vuorovaikutuksen tarpeellisuudesta ja keskustelun merkityksellisyydestä. Tätä päätelmää vahvistavat omat etnografiset havaintomme hoitokotien arjesta ja vuorovaikutuksesta. Kuva 2 havainnollistaa aineistostamme nousevia vanhuslähtöisen kielen tunnusmerkkejä.

Kuva 2 pyrkii kuvaamaan, kuinka moniulotteinen ilmiö ajatus vanhuslähtöisestä kielestä vanhusten hoitokodissa on. Toimintaympäristönä vanhusten hoitokoti on 


\section{Vanhuslahtoisen kielen TUNNUSMERKKEJÄ:}
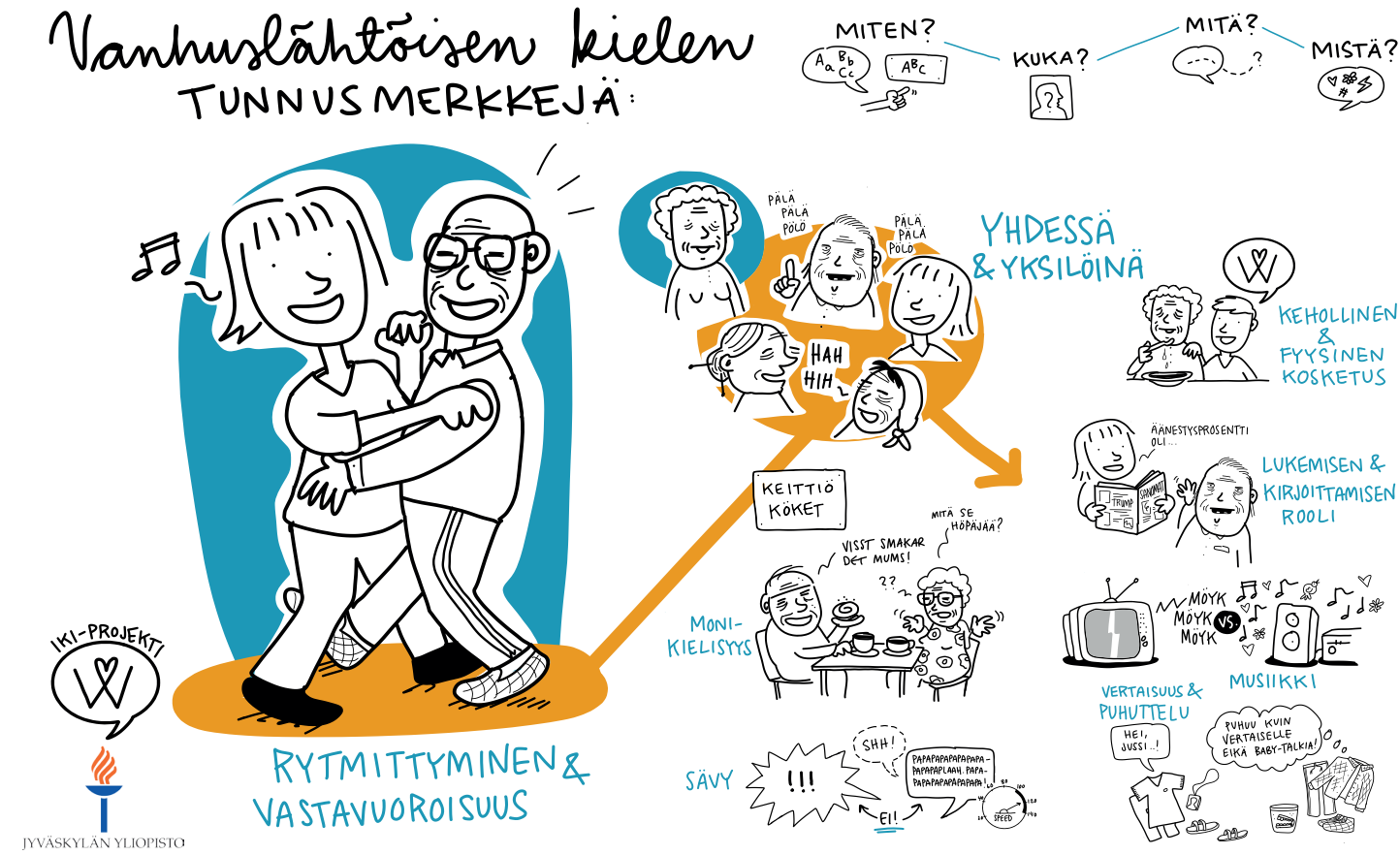

lailla säädelty institutionaalinen paikka, joka on asukkaille koti ja hoitajille ja esimiehille työpaikka. Jo nämä toisistaan selvästi poikkeavat positiot luovat erilaiset tarpeet ja toiveet vuorovaikutukselle ja kielenkäytölle: siinä missä hoitajat pyrkivät tekemään työnsä tarkoituksenmukaisesti ja sujuvoittamaan hoitoarkea, asukkaat kaipailevat keskustelua, rupattelua ja yhteistä toimintaa hoivakodin arkeen. Hoitajien kielikäsityksissä korostuvat puheen ymmärrettävyys ja selkeys, asukkailla taas kielen sosiaalinen sidoksisuus, keskustelu ja kuunteleminen. Tutkimuksen perusteella voikin sanoa, että sekä hoitajien, esimiesten että asukkaiden kielikäsitykset perustuvat samansuuntaisiin funktionaalisiin kieli-ideologioihin, mutta hieman eri tavoin. Hoitajien ja esimiesten käsitykset kielestä implikoivat ja indeksoivat selvemmin välineellistä kieliideologiaa, jossa kielen arvo ja merkitys määrittyy instituution ja toimijoiden tehtävistä käsin. Asukkaiden käsitykset taas viittaavat pikemminkin kielen sosiaalisuutta ja vuorovaikutusta rakentavaan tehtävään, jossa kielen arvo on (arkisen) toiminnan sosiaalisuudessa. Kumpaankin näihin liittyy myös yksi-, kaksitai monikielisyyden ideologioita: äidinkielen merkitys kaksikielisessä ympäristössä korostuu hoitajien ja esimiesten käsityksissä itsestään selvänä, kun taas asukkaiden ja hoitajien käsityksissä monikielisyys näyttäytyy myös käytännöllisenä välineenä ja vuorovaikutuksen osana (ja haasteena tai esteenä).

Tutkimuksessa esiin tulleiden erilaisten tarpeiden ja toiveiden yhteensovittamista vanhuslähtöisen kielen näkökulmasta voidaan hahmotella kahden toisiinsa liittyvän metajäsennyksen kautta: (1) yksilönä ja ybdessä sekä (2) rytmittäminen ja vuorovaikutus (ks. kuva 2).

Yksilönäja yhdessä liittyy keskeiseen arvoon kohdella jokaista vanhusta yksilönä, mikä 
vuorovaikutuksen tasolla näkyy esimerkiksi henkilön oman nimen käyttämisenä ja henkilöhistorian huomioimisena keskustelussa ja hoitotoimenpiteissä. Yhdessä viittaa erityisesti asukkaiden toiveeseen yhteisestä toiminnasta ja keskustelusta. Tutkimuksemme perusteella vanhusten keskinäinen, tuettu keskustelu oli niukasti hyödynnetty resurssi. Vuorovaikutusta etenkin huonomuistisemmilla asukkailla oli lähinnä hoitajien kanssa, mitä toki selittävät toimintakykyisyyden erot ja hoitajien ammattikäytänteet. Mikäli keskustelua ja osallisuutta halutaan hoitokodin arjessa lisätä, tuettu vuorovaikutus asukkaiden kesken voisi olla yksi keino. Näihin keinoihin lukeutuu monikielisessä kontekstissa myös tulkkaus. Laajemman toimintaympäristön kannalta tuloksemme merkitsee esimerkiksi sitä, että yhteiskunnallisissa ja poliittisissa diskursseissa voisi olla syytä yksilöllisyyden - esimerkiksi yksilöllisen hoivan ja kotona asumisen takaamisen - sijaan korostaa yhdessä toimimista.

Rytmittämisellä ja vastavuoroisuudella viittaamme havaintoihimme hyvistä vuorovaikutustilanteista, joissa keskustelua syntyi ja joissa asukas oli aktiivisena osallistujana. Näissä tilanteissa toimintakykyisempi henkilö (usein hoitaja) rytmitti taitavasti keskustelua ja toimintaa yhtäältä suhteessa tilanteeseen (ruokailu, televisionkatselu), toisaalta suhteessa asukkaan kykyyn viestiä ottamalla huomioon esimerkiksi puheentuottamisen hitauden ja nonverbaalisen osallistumisen (katse, eleet, ilmeet). Näin vuorovaikutus rakentui vastavuoroisuudelle ja mahdollisuus osallisuuteen rakentui silloinkin, kun asukkaan oma viestintärepertuaari oli jollain tapaa rajoittunut.

Kuten aiemmassa tutkimuksessa, myös tässä fokus on ollut paljolti hoitajien kielenkäytössä, vaikka joissain esimerkeissä nousee esiin vanhusten välinen vuorovaikutus etuineen ja ongelmineen (etenkin kaksi- ja monikielisyyden haasteet). Vanhusten keskinäistä vuorovaikutusta on tutkittu maailmalla ja
Suomessakin vielä vähäisesti (ks. kuitenkin Lindholm, 2012; Mononen, 2016), joten tutkimukselle on edelleen tarvetta. Oma tutkimuksemme nostaa lisäksi esiin tarpeen tutkia vanhustyön kontekstia monikielisyyden ja esimerkiksi tulkkauksen näkökulmasta.

Genreinnovaatio tutkimusta raportoivasta - vaikka yleistajuisestakin - tekstistä kuvasarjaksi toteuttaa nähdäksemme hyvin yhtä kriittisen diskurssintutkimuksen perusajatusta: kieltä muokkaamalla mahdollistuu myös toiminnan muuttaminen. Uudistamalla ja muokkaamalla sitä tapaa, jolla tutkimustuloksia esitetään, pyrimme tässä tutkimuksessa tosissamme edistämään tutkimustiedon vaikutusta tutkittavien maailmaan. Tapaustutkimuksen lopuksi veimme kuvasarjan julisteineen niihin paikkoihin ja niille avainhenkilöille, joiden kanssa tutkimustyötä oli yhteistyössä tehty, ja kävimme niitä yhdessä keskustellen läpi. Julisteina ja postikortteina toteutetulla kuvasarjalla hyvät käytänteet saadaan myös konkreettisesti näkyväksi juuri siellä, missä vanhukset ja vanhustyön tekijät ja ajoittain omaisetkin ovat eli hoitoyksikön tiloissa.

Geriatrisen hoidon ja vanhustyön kehittämisessä on suosituksina masennuksen ehkäisyyn mainittu useita osa-alueita, joissa kielenkäytöllä on keskeinen rooli: muiden muassa aktivointi ja virikkeellinen toiminta, televisiouutisten hidas tempo ja selkokielisyys, totuudenmukainen tiedottaminen ikääntymisestä ja iäkkäistä, vanhusten arvostamisen parantaminen, yhteisöllisyyden herättäminen sekä muisteluterapian tai muistelutyön toteuttaminen vuorovaikutuksessa useiden eri toimijoiden kanssa (Kivelä, 2006, s. 93-97). Jo olemassa oleva selkokielen tutkimus tarjoaa näkökulmia, miten pyrkiä kielellisesti ihmisten yhdenvertaiseen, tasa-arvoiseen kohteluun, muun muassa osallistamalla kohdeyleisöä heille suunnattujen materiaalien testaajina (Kulkki-Nieminen, 2010; Virtanen, 2015). 
Epäsymmetristen ja haastavien vuorovaikutustilanteiden tutkimus voi myös tarjota välineitä tasa-arvoisten, osallistavien vuorovaikutuskäytänteiden rakentamiseen $(\mathrm{mm}$. Leskelä, 2012). Omien tulostemme pohjalta näiden lisäksi tulisi kiinnittää enemmän huomiota vanhusten keskinäiseen vuorovaikutukseen sekä monikielisyyden haasteisiin, joita kohtaavat kaikki vanhustyön toimijat niin asukkaat, hoitajat kuin omaisetkin - ja jatkossa yhä useammin.

\section{LÄHTEET}

Aaltonen, T., Henriksson, L., Karttunen, A., Kivimäki, R., Palukka, H., Silvennoinen-Nuora, L., Tiilikka, T. \& Valokivi, H. (2009). Toimijat vanhusten hyvinvointipalveluja ohjaavissa kehittämisohjelmissa. Kunnallistieteellinen aikakauskirja, 37, 336-352.

Aineistonhallinnan käsikirja. Tampere: Yhteiskuntatieteellinen tietoarkisto. urn:nbn:fi:fsd:V-201504200001. Haettu 23.11.2017 osoitteesta <http:// www.fsd.uta.fi/aineistonhallinta/ > urn:nbn:fi:fsd:V-201504200001

Andersson, S., Haverinen, R. \& Malin, M. (2004). Vanhusten kotihoito kolmesta näkökulmasta. Vanhukset, työntekijät ja johto integroinnin ja asiakaskeskeisyyden arvioijina. Yhteiskuntapolitiikka, 69, 481-494.

Backhaus, P. (2009). Politeness in institutional elderly care in Japan: A cross-cultural comparison. Journal of Politeness Research, 5, 53-71.

Bialystok, E., Abutalebi, J., Bak, T., Burke, D. and Kroll, J. (2016). Aging in two languages: Implications for public health. Ageing Research Reviews, 27, 56-60.

Cantarella, L., Hegel C. \& Marcus E. (2015). A week in Pasadena: Collaborations towards a design modality for ethnographic research. Field, $1,53-94$.

Carpiac-Claver, M. L. \& Levy-Storms, L. (2007). In a manner of speaking: Communication between nurse aides and older adults in longterm care settings. Health Communication, 22, 59-67.

Coupland, N. (1997). Language, ageing and ageism: A project for applied linguistics? International Journal of Applied Linguistics, 7 , 26-48.

Coupland, N. \& Coupland, J. (1993). Discourses of ageism and anti-ageism. Journal of Aging Studies, 7, 279-301.

Cruikshank, M. (2003). Learning to be old: Gender, culture, and aging. Lanham: Rowman \& Littlefield.

Fealy, G., McNamara, M., Treacy, M. P. \& Lyons, I. (2012). Constructing ageing and age identities: A case study of newspaper discourses. Ageing and Society, 32, 85-102.

Grainger, K. (1993). "That's a lovely bath dear": Reality construction in the discourse of elderly care. Journal of Aging Studies, 7, 247-262.

Grainger, K. (1998). Reality orientation in institutions for the elderly: The perspective from interactional sociolinguistics. Journal of Aging Studies, 12, 39-56.

Grainger, K. (2004). Communication and the institutionalized elderly. Teoksessa J. F. Nussbaum \& J. Coupland (toim.), Handbook of communication and aging research, (s. 479-497). Mahwah: Laurence Erlbaum Associates.

Hamilton, H. (2008). Language and dementia: Sociolinguistic aspects. Annual Review of Applied Linguistics, 28, 91-110.

Heinemann, T. (2009). Managing unavoidable conflicts in caretaking of the elderly: humor as a mitigating resource. International Journal of the Sociology of Language, 200, 103-127.

Heller, M., Pietikäinen, S. \& Pujolar, J. (2018). Critical sociolinguistic research methods. How to study language issues that matter. New York: Routledge.

Isosävi, J. \& Lappalainen, H. (2015). Johdanto. Teoksessa J. Isosävi \& H. Lappalainen (toim), Saako sinutella vai täytyykö teititellä? Tutkimuksia eurooppalaisten kielten pubuttelukäytännöis$t \ddot{a}$, (s. 9-33). Helsinki: Suomalaisen Kirjallisuuden Seura.

Jansson, G. (2014). Bridging language barriers in multilingual care encounters. Multilingua, 33, 201-232.

Jansson, G. \& Plejert, C. (2014). Taking a shower: Managing a potentially imposing activity in dementia care. Journal of Interactional Research in Communication Disorders, 5, 27-62.

Kinnunen, T. (2015). Suunvuoro. Virittäjä, 119, 
315-316.

Kivelä, S.-L. (2006). Geriatrisen hoidon ja vanhustyön kehittäminen. Selvityshenkilön raportti. Sosiaali- ja terveysministeriön selvityksiä 30 . Helsinki: Sosiaali- ja terveysministeriö.

Korolija, N. (2000). Coherence-inducing strategies in conversations amongst the aged.Journal of Pragmatics, 32, 425-462.

Korpijaakko-Huuhka, A.-M., Rantala, L. \& Karjalainen, M. (2014). Mutta minä rompotan menemään. Dementoituvan ihmisen kielellistetty identiteetti. Puhe ja kieli, 34, 55-79.

Kroskrity, P. V. (2004). Language ideologies. Teoksessa A. Duranti (toim.), A companion to linguistic anthropology, (s. 496-517). Malden, MA: Blackwell.

Kulkki-Nieminen, A. (2010). Selkoistettu uutinen. Lingvistinen analyysi selkotekstin erityispiirteistä. Tampere: Tampereen yliopisto 2010. Saatavilla Internetissä: http://acta.uta.fi/pdf/978951-44-8093-5.pdf

Lappalainen, H. (2015). Sinä vai te vai sekä että? Puhuttelukäytännöt suomen kielessä. Teoksessa J. Isosävi \& H. Lappalainen (toim.), Saako sinutella vai täytyykö teititellä? Tutkimuksia eurooppalaisten kielten pubuttelukäytännöistä, (s. 72-104). Helsinki: Suomalaisen Kirjallisuuden Seura.

Lappalainen, H. (2016). Kuka kaipaa teitittelyä? Gerontologia, 30, 46-47.

Leskelä, L. (2012). Selkokielisen vuorovaikutuksen ohjeet. Teoksessa L. Leskelä \& C. Lindholm (toim.), Haavoittuva keskustelu: Keskusteluanalyyttisia tutkimuksia kielellisesti epäsymmetrisestä vuorovaikutuksesta, (s. 279-298). Helsinki: Kehitysvammaliitto.

Levy, B. R., Ferrucci, L., Zonderman, A. B., Slade, M. D., Troncoso, J. \& Resnick, S. M. (2016). A culture-brain link: Negative age stereotypes predict Alzheimer's disease biomarkers. Psychology and Aging, 31, 82-88.

Lindholm, C. (2006). Det är som sjutton också. Kiinteät ilmaukset dementiaa sairastavien vanhusten ja hoitajien keskusteluissa. Puhe ja kieli, 26, 185-199.

Lindholm, C. (2012). Vuorovaikutuksen haasteita ja mahdollisuuksia - tapaustutkimus muistisairaiden päivätoiminnasta. Teoksessa L. Leskelä \& C. Lindholm (toim.), Haavoittuva keskustelu: keskusteluanalyyttisia tutkimuksia kielel- lisesti epäsymmetrisestä vuorovaikutuksesta, (s. 57-98). Helsinki: Kehitysvammaliitto.

Lindholm, C. (2015). Parallel realities: The interactional management of confabulation in dementia care encounters. Research on Language and Social Interaction, 48, 176-199.

Lindholm, C. (2017). Ageing as a Swedishspeaking Finn: Positioning and language choice at a nursing home. Teoksessa C. Plejert, C. Lindholm \& R. Schrauf (toim.), Multilingual Interaction and Dementia, (s. 23-51). Bristol: Multilingual Matters.

Makkinga, J. (2017). Belonging to the old and unsuccessfully aged: Language practices in a home in Maastricht, The Netherlands. JASO-online Journal of the Anthropological Society of Oxford, 9, 83-101.

Makoni, S. \& Grainger, K. (2002). Comparative gerontolinguistics: Characterizing discourses in caring institutions in South Africa and the United Kingdom. Journal of Social Issues, 58, 805-824.

Markkola, P. (2003). Muuttuuko vanhusten kieli? Gerontologia, 3, 170.

Marsden, S. \& Holmes, J. (2014). Talking to the elderly in New Zealand residential care settings. Journal of Pragmatics, 64, 17-34.

Mononen, K. (2013). Inkerinsuomalaisten suomen kielen käyttö Pietarissa ja sen läbialueella. Helsinki: Helsingin yliopisto.

Mononen, K. (2016). Muisti ja kuulo osana sosiaalista toimintaa inkerinsuomalaisten vanhusten keskusteluissa. Virittäjä, 120, 30-56.

Mäntynen, A., Halonen, M., Pietikäinen, S. \& Solin, A. (2012). Kieli-ideologioiden teoriaa ja käytäntöä. Virittäjä, 116, 325-348.

Nussbaum, J. F., Pitss, M. J., Huber, F. N, Raup Krieger, J. L. \& Ohs, J. E. (2005). Ageism and ageist language across the life span: Intimate relationships and non-intimate Iinteractions. Journal of Social Issues, 61, 287-305.

Mielikäinen, A. \& Palander, M. (2014). Miten suomalaiset puhuvat murteista? Kansanlingvistinen tutkimus metakielestä. Helsinki: Suomalaisen Kirjallisuuden Seura.

Pekkala, S. (2011). Normaaliin ikääntymiseen liittyvät kielelliset muutokset ja niiden syyt. Gerontologia, 25, 35-43.

Pietikäinen, S. (2016). Critical debates: discourse, boundaries and social change. Teoksessa N. 
Coupland (toim.), Sociolinguistics: Theoretical debates (s. 263-281). Cambridge: Cambridge University Press.

Pietikäinen, S. \& Mäntynen, A. (2009). Kurssi kohti diskurssia. Tampere: Vastapaino.

Plejert, C., Jansson, G. \& Yazdanpanah, M. (2014). Response practices in multilingual interaction with an older Persian woman in a Swedish residential home. Journal of Cross-Cultural Gerontology, 29, 1-23.

Plejert, C., Lindholm, C. \& Schrauf, R. W. (2017). Multilingual interaction and dementia. Teoksessa C. Plejert, C. Lindholm \& R. Schrauf (toim.), Multilingual Interaction and Dementia, (s. 1-22). Bristol: Multilingual Matters.

Preston, D. R. (2004). Folk metalanguage. Teoksessa A. Jaworski, N. Coupland \& D. Galasinski (toim.), Metalanguage. Social and ideological perspectives, (s. 75-101). Berlin: Mouton de Gruyter.
Ryan, E. B., Spykerman, H. \& Anas, A. P. (2005). Writers with dementia: The interplay among reading, writing, and personhood. Teoksessa B. H. Davis (toim.), Alzheimer talk, text and context: Enhancing communication, (s. 190-198). New York: Palgrave Macmillan.

Saviniemi, M. (2015). "On noloa, jos ammattilaiset tekevät tökeröitä kielioppivirheitä." Toimitusbenkilökunnan kielenbuoltotiedot, -käytännöt ja-diskurssit. Väitöskirja. Acta Universitatis Ouluensis B Humaniora 127. Oulu: Oulun yliopisto.

Woolard, K. A. (1998). Introduction. Language ideology as a field of inquiry. Teoksessa P. V. Kroskrity, K. A. Woolard \& B. B. Schieffelin, (toim.), Language Ideologies: Practice and theory, (s. 3-47). New York: Oxford University Press. 


\section{LIITE 1: LITTEROINTIMERKIT}

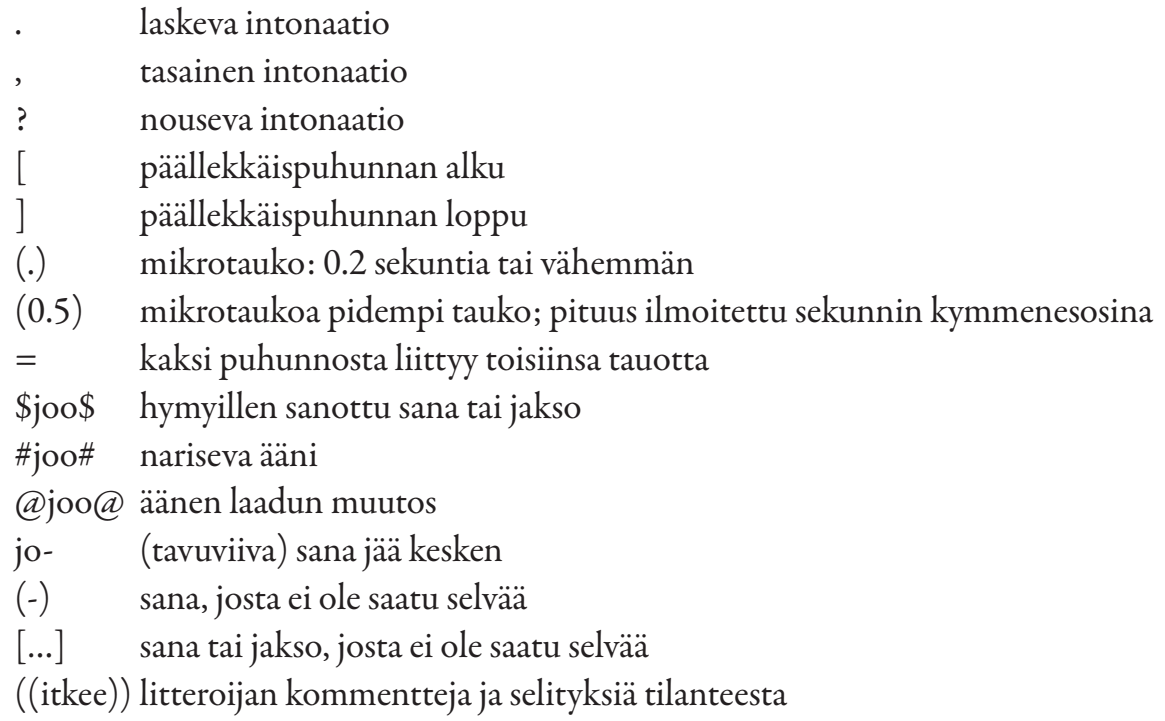




\section{LANGUAGE IDEOLOGIES IN ELDERCARE - CONCEPTIONS OF EFFECTIVE COMMUNICATION AND LANGUAGE USE BY THE RESIDENTS, NURSES AND MANAGERS OF RETIREMENT HOMES}

Anne Mäntynen, Department of Finnish, Finno-Ugrian and Scandinavian Studies, University of Helsinki

Sanna Tapionkaski, Department of Language and Communication Studies, University of Jyväskylä

Sari Pietikäinen, Department of Language and Communication Studies, University of Jyväskylä

In this article, we apply critical discourse analysis and ethnography to examine conceptions and experiences of inclusive interaction and language use in the context of eldercare in a retirement home. Our data consist of interviews with residents, nurses and managers in two bilingual eldercare units, as well as ethnographic observations of communication and language use in these units. Our analysis focuses especially on language ideologies and metalinguistic aspects of inclusive language in the context of eldercare. On the basis of our analysis, we suggest that four elements are particularly central to elderly-centric language: 1) the quality, quantity and tone of interaction; 2) the practices of addressing people and using names; 3 ) the use of mother tongue and multilingualism; and 4) the significance of touch and other multimodal interaction. The results indicate that the care units are both a home for the residents and a working place for the nurses and managers. These diverging positions generate different needs and expectations for interaction and language use: while the nurses aim to function well in their work in order to make everyday care sensible and efficient, the residents desire conversation, chatting and shared activities. Nurses emphasize understandability and clarity of speech, whereas residents focus on social bonding and interaction. The results also indicate that methods such as supported mutual interaction between the elderly residents, as well as the activating use of music, could increase inclusive interaction in the retirement home.

Keywords: discourse analysis, eldercare, elderly-centric language, ethnography, inclusive interaction, language ideologies 